\title{
Identification of tectonically active areas using DEM: a quantitative morphometric analysis of Mt. Medvednica, NW Croatia
}

\author{
Bojan MATOŠ ${ }^{1, *}$, Bruno TOMLJENOVIĆ ${ }^{1}$ and Neven TRENC ${ }^{2}$ \\ 1 Faculty of Mining, Geology and Petroleum Engineering, University of Zagreb, Pierottijeva 6, Zagreb, Croatia \\ 2 State Institute for Nature Protection, Trg Mažuranića 5, Zagreb, Croatia
}

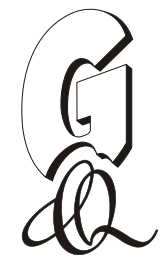

Matoš B., Tomljenović B. and Trenc N. (2013) Identification of tectonically active areas using DEM: a quantitative morphometric analysis of Mt. Medvednica, NW Croatia. Geological Quarterly, 58 (1): 51-70, doi: 10.7306/gq.1130

\begin{abstract}
Mt. Medvednica is an inselberg in NW Croatia, which lies at the intersection between the Southeastern Alps, Northwestern Dinarides and Tisza Mega-Unit of the Pannonian Basin. Due to the Pliocene-Quaternary N-S directed shortening, Mt. Medvednica experienced 1500-2000 m of differential uplift and now exposes pre-Neogene and Neogene tectonic and stratigraphic units that are surrounded by Pliocene-Quaternary sediments. This paper evaluates a set of quantitative morphometry methods used to identify tectonically active areas within this region characterized by low-rate active folding and faulting during the Pliocene-Quaternary. Our analysis employed extraction of hypsometric curves, calculation of a hypsometric integral, asymmetry factor, and statistical parameters of longitudinal stream profiles along 36 drainage basins delineated from a $25 \mathrm{~m}$ resolution DEM of Mt. Medvednica area. Despite lithological heterogeneity of the study area, the morphometric parameters we obtain are good indicators for discriminating tectonically active from inactive areas. We interpret that the most tectonically active areas are located at the SW corner and in the central part of Mt. Medvednica, where they are likely related to the North Medvednica Boundary Fault, and to the Kašina Fault, respectively. The latter divides the range into distinct NE and SW morphological and structural areas.
\end{abstract}

Key words: DEM, hypsometry, asymmetry factor, longitudinal stream profiles, active tectonics, Mt. Medvednica.

\section{INTRODUCTION}

Digital Elevation Models (DEMs) have been used in quantitative morphotectonic analysis to understand the relationship between tectonic activity, associated landscape features and evolution. This method has been widely tested in tectonically active areas of variable deformation rates, including high strain rate areas such as the western USA, Taiwan and Himalaya (e.g., Snyder et al., 2000; Champel et al., 2002; Delcaillau et al., 2006), and in low strain rate areas like SE Spain (Pedrera et al., 2009; Pérez-Peńa et al., 2010), southern and northern Italy (Guernieri and Pirrotta, 2008; Picotti et al., 2009), the Vienna Basin and Central Pannonian Basin region (Ruszkiczay-Rüdiger et al., 2009; Beidinger et al., 2011). These results are often combined with additional data, e.g. from structural geology/tectonics, seismology and geodesy to provide an easily obtained and reliable tool in understanding landscape evolution, potential natural hazards and land-use planning in densely populated areas (Bishop, 2007; Ruszkiczay-Rüdiger et al., 2009; Pérez-Peńa et al., 2010). A great number of geomorphic indices have been developed that

\section{* Corresponding author, e-mail: bojan.matos@rgn.hr}

Received: June 19, 2013; accepted: October 18, 2013; first published online: November 15, 2013 can be extracted and calculated from the present-day topography (i.e. DEMs), which serve to quantify ongoing tectonic processes and rates of uplift and subsidence related to folding and faulting (e.g., Keller et al., 2000; Keller and Pinter, 2002; Pinter, 2005; Bull, 2009).

This paper presents a DEM-based morphometric analysis aimed to identify tectonically active areas at Mt. Medvednica, a ca. $35 \mathrm{~km}$ long and $10 \mathrm{~km}$ wide hilly terrain in the SW corner of the Pannonian Basin in Croatia. We extracted and calculated geomorphic indices (hypsometric curves and integrals, asymmetry factors and normalized longitudinal stream profiles) for 36 Mt. Medvednica drainage basins that we then compared to separate those representing tectonically active vs. inactive sub-areas. These new data were then compared with the results from previous geomorphologic, neotectonic and seismotectonic studies of this area (Hećimović, 1984, 2000; Prelogović et al., 1998; Tomljenović and Csontos, 2001; Tomljenović et al., 2008; Herak et al., 2009).

\section{GEOLOGICAL AND TECTONIC SETTING}

Mt. Medvednica is a NE-SW-trending inselberg at the SW corner of the Pannonian Basin, which lies near the junction between the SE Alps, NW Dinarides and Tisza Mega-Unit of the Pannonian Basin (Fig. 1). Its present-day position and trend are explained by an eastward displacement (tectonic escape) and 


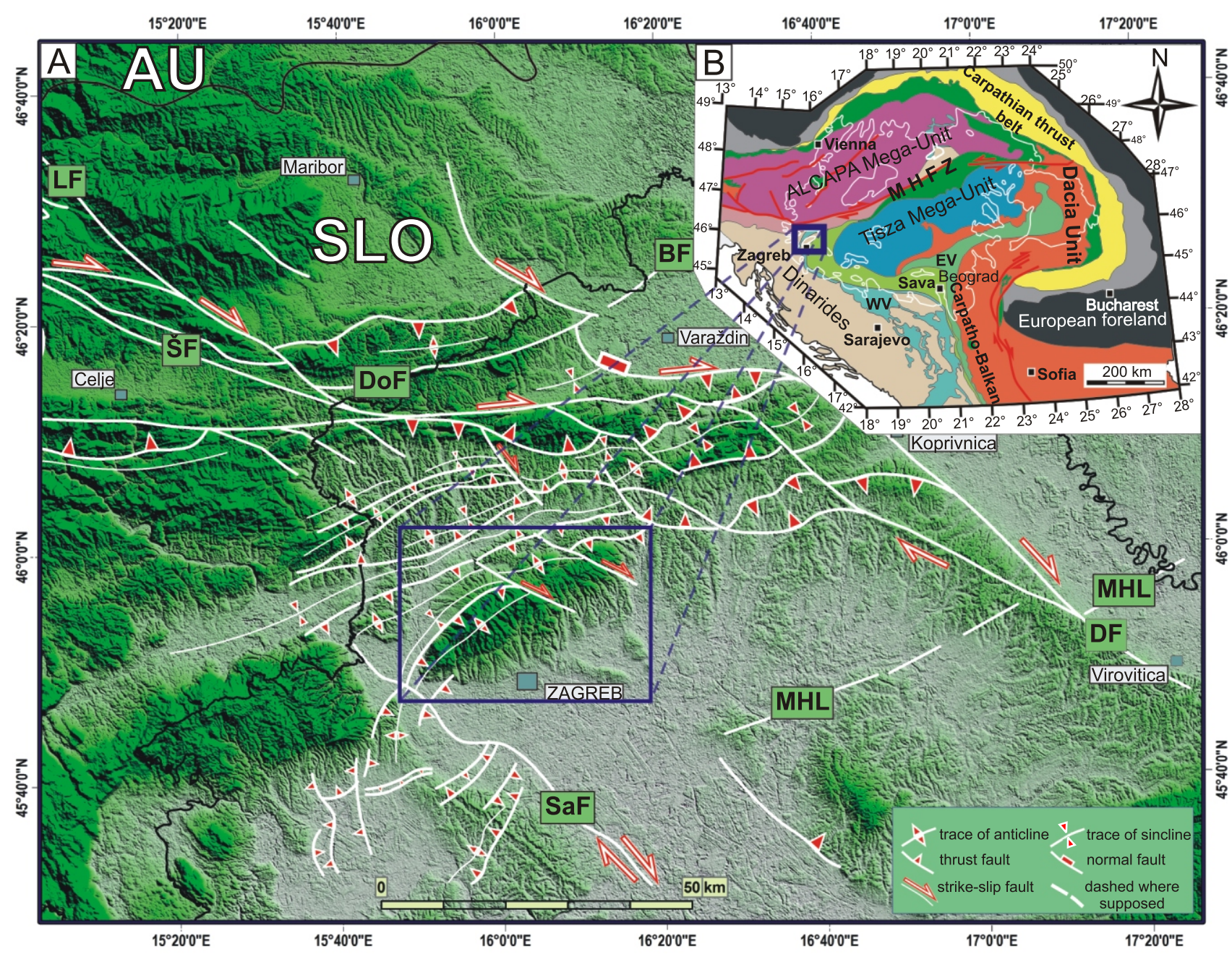

Fig. 1A - major Late Pontian to recent map-scale reverse, normal and strike-slip faults and folds in the border zone of the SE Alps, Dinarides and Pannonian Basin in Slovenia and Croatia (slightly modified after Tomljenović and Csontos, 2001 with references therein); B - shows the study area within simplified tectonic framework of the Alps, Carpathians and Dinarides (simplified after Schmid et al., 2008 and Ustaszewski et al., 2009)

BF - Balaton Fault, DF - Drava Fault, DoF - Donat Fault, LF - Labot Fault, MHL - Mid-Hungarian line, SaF - Sava Fault in Croatia, ŠF - Šoštanj Fault

approx. $130^{\circ}$ clockwise rotation of the tectonic block comprising Medvednica and its surrounding inselbergs during the Latest Paleogene-Earliest Neogene (Márton et al., 2002; Tomljenović et al., 2008). These movements were probably related to the initial stage of Miocene eastward extrusion of wedge-shaped crustal blocks of the Eastern Alps-Pannonian Basin transition. Several kinematic models exist to explain this process (e.g., Ratschbacher et al., 1991; Fodor et al., 1998 with references therein). In the Alpine-Pannonian Basin transitional area, lateral extrusion was controlled by dextral transpression between the Periadriatic-Balaton and Mid-Hungarian fault systems (ŠF, DoF segments, BF and $\mathrm{MHL}$ in Fig. 1; e.g., Csontos and Nagymarosy, 1998; Fodor et al., 1998; Csontos et al., 2005) that strongly affected Mt. Medvednica and its surroundings.

The present-day topography of Mt. Medvednica and the hilly terrain to the north of it, which extends into Slovenia (Zagorje Region), is strongly controlled by the presence of Late Miocene-Quaternary folds and pop-up structures (e.g., Takšić, 1965; Šimunić et al., 1983; Tomljenović and Csontos, 2001). These structures mark the eastward prolongation of the Sava folds region of Slovenia (Sikošek, 1971; Placer, 1999), a zone of active E-W to NE-SW-trending ranges (anticlines) and valleys (synclines; Fig. 1). The final stage in the formation of these folds, which commenced during the latest Miocene (ca. $6 \mathrm{Ma}$ ) under a N-S to NW-SE directed shortening, is well-documented by outcrop structural analyses and seismic reflection data (e.g., Fodor et al., 1998; Gosar, 1998; Prelogović et al., 1998; Vrabec, 1999; Tomljenović and Csontos, 2001). In addition to folding, the shortening was accommodated by pervasive brittle deformation and the formation of $\mathrm{E}-\mathrm{W}$-striking reverse faults. The folds and reverse faults are commonly offset by NW-SE-striking dextral faults (Fig. 1). Continuation of tectonic activity from the Late Miocene into the Pliocene and Quaternary is locally well-documented, e.g. by 70 metres of vertical offset of a Pliocene coal-seam along the Šoštanj Fault (ŠF in Fig. 1; Vrabec, 1999), by tilting and folding of Upper Miocene-Pliocene strata (Gosar, 1998), by an offset of Pleistocene deposits along both limbs of the Krško Syncline $25 \mathrm{~km}$ NW of Mt. Medvednica (Verbič, 2005), and by folding and presumably faulting of the basal Pliocene-Quaternary strata along the Northern Medvednica Boundary Fault, as observed in seismic sections (NMBF in Fig. 2; Tomljenović and Csontos, 2001). Based on 
these studies, this area is considered to be tectonically active, with low uplift rates of ca. $0.023 \mathrm{~mm} / \mathrm{y}$ (based on data from Vrabec, 1999) and fault-slip rates of $0.04-0.46 \mathrm{~mm} / \mathrm{y}$ (Verbič, 2005). The regional data are in good agreement with the $0.17-0.4 \mathrm{~mm} / \mathrm{y}$ Quaternary uplift rate reported by Kuk et al. (2000) for the central part of Mt. Medvednica.

The current structural architecture of Mt. Medvednica (Fig. 2) has been strongly affected by Late Miocene-Quaternary deformations described above. The central part of the mountain is an asymmetric antiform composed of mid-Cretaceous (122-110 Ma) greenschists and overlying lower-grade metasedimentary rocks (e.g., Belak et al., 1995; Judik et al., 2004, 2008; Lugović et al., 2006; Tomljenović et al., 2008). This unit has been overthrusted by a Jurassic ophiolitic mélange (Halamić et al., 1998, 1999; Babić et al., 2002; Lugović et al., 2006; Slovenec and Lugović, 2008) that is preserved in an adjacent synform to the north. Both of these units are unconformably covered by Senonian-Paleocene (Gosau-type see Willingshofer et al., 1999 and references therein) shallow-marine to basinal sequences (Babić et al., 1973; Crnjaković, 1980, 1987). The highest unit of the pre-Neogene structural assemblage is represented by a Triassic shallow-marine succession of the Žumberak nappe which is locally preserved in the SW part of the mountain (Fig. 2A), where it thrusts over Senonian-Paleocene sequences (Šikić et al., 1979). These pre-Neogene basement units are unconformably covered by Middle and Late Miocene sediments (starting with Ottnangian clastics, ca. 17.5 Ma) deposited within the North Croatian sub-basin of the Pannonian Basin system (e.g., Pavelić, 2001; Saftić et al., 2003; Kovačić et al., 2004; Vrsaljko et al., 2006; Ćorić et al., 2009 with references therein). Overlying Pliocene sediments are composed of alluvial to lacustrine sediments, which grade upward into Pleistocene silts and clays, locally of aeolian origin (loess), deposited in ponds and marshy environments (Šikić et al., 1977; Basch, 1981; Velić and Saftić, 1991; Velić and Durn, 1993; Velić et al., 1999). The youngest Quaternary gravels and sands that accumulated in three aggradational terraces are exposed on both sides of the Sava River at elevations between 108-124 m (Šikić et al., 1977; Basch, 1981). Contemporaneous clastics of proluvial origin are deposited in creeks and alluvial fans at the base of the slopes of Mt. Medvednica.

Due to the latest Miocene-Quaternary deformation, the structural position of Miocene sediments is remarkably different along the strike of the Medvednica antiform. In its northeastern part, i.e. to the NE of the Kašina Fault (KF in Fig. 2), Miocene sediments unconformably cover both limbs of the antiform and are dipping parallel to the dip of both antiform limbs. By contrast, in the southwestern part of the mountain, i.e. to the south-east of the Kašina Fault, the base-Miocene unconformity is exposed only along the southeastern slope at the elevation between 200 and $400 \mathrm{~m}$, while on the northwestern slope, it is missing at the surface. There, the base-Miocene unconformity is either overthust by pre-Neogene basement units (hangingwall of the NMBF) or is covered by up to $400 \mathrm{~m}$ thick Pliocene-Quaternary sediments. It implies possibilities of exposition of the NMBF segment near the Kašina Fault, and its southwestern extension along the base of the northwestern slope. This interpretation is supported by the Bouguer gravity anomaly map of Aljinović (published in Verbič, 2005), which indicates a sharp transition from a positive (Medvednica antiform) into a negative gravity anomaly located in front of the southwestern termination of the mountain (Fig. 2B). This negative anomaly corresponds with the deepest part of a ca. $20 \mathrm{~km}$ long and $6 \mathrm{~km}$ wide syncline composed of Miocene-Quaternary sediments here projected into the profile $\mathrm{A}-\mathrm{B}$ of Figure $2 \mathrm{C}$. A cumulative vertical offset of the base-Middle Miocene uncon- formity along NMBF splay faults is about $3750 \mathrm{~m}$, which would account for ca. $0.27 \mathrm{~mm} / \mathrm{y}$ slip rate along the NMBF since the Middle Miocene (Late Badenian, ca. $14 \mathrm{Ma}$ ) time. In the north-east direction of the NMBF, the total vertical offset of the base-Middle Miocene unconformity along this fault decreases, indicated by a more gradual transition from a positive into a negative gravity anomaly (Fig. 2B). Therefore, we are in the opinion that tectonic activity along the NMBF either shifted from its northeastern toward the southwestern termination or that the displacement along the same fault was unevenly distributed during Late Miocene-Quaternary times.

\section{GEOMORPHOLOGICAL SETTING}

The most evident landscape feature in Mt. Medvednica (total area of $\sim 442 \mathrm{~km}^{2}$ ) is a mountain ridge with a general NE-SW trend extending between the Sava and Lonja rivers (Fig. 3). The mountain is bounded to the north by the Krapina River valley. The highest elevations are concentrated in the SW area of the mountain (with the highest peak Sljeme at $1032 \mathrm{~m}$ ), which is characterized by up to $900 \mathrm{~m}$ of local relief, while local relief values in the NE area does not exceed 500 m (Fig. 4B). The considerable elevation differences have been used in previous classifications of local morphostructures according to Hećimović (2000) and Bognar (2001).

Most of the landscape features in Mt. Medvednica are related to slope gravitational processes, controlled by creeping and especially land-sliding in parts where Miocene laminated clayey marl and clays are in contact with coarse-grained Neogene or pre-Neogene rocks (Vrsaljko et al., 2011; Mihalić et al., 2011). In areas where carbonate rocks prevail, e.g. in the SW corner of Mt. Medvednica, the landscape is controlled by karstic and fluvio-karstic erosional processes. Short and predominantly narrow stream valleys with the lengths $<4.5 \mathrm{~km}$ prevail in the western part of Mt. Medvednica in contrast to the rest of the mountain where the drainage network is more developed and the lengths of valleys are $>4 \mathrm{~km}$ (Table 1). The stream network often shows a rectangular pattern and sudden sharp changes in flow direction, which, according to previous studies (Prelogović, 1975; Hećimović, 1984, 2000), are either linked to major lithological boundaries or are related to ongoing tectonic activity.

\section{METHODS AND RESULTS}

\section{DEM AND DELINEATION OF DRAINAGE BASINS}

The morphometric analysis was performed using a $25 \mathrm{~m}$ resolution DEM that was constructed using elevation points provided by the Croatian Geodetic Survey and projected in EPSG projection 31275 (MGl/Balkans zone 5 - one of two national projection systems of Croatia). Elevation points were extrapolated by photogrammetric restitution of aerial orthophotos. The DEM was modelled and analysed using ESRI ArcMap software (version 9.3.1.). The first step in a DEM-based morphometric analysis was extraction of the drainage network and drainage basins. It was conducted using ESRI ArcMap software, extension ArcHydro version 1.1 following methodology described by Tarboton (1997) and Peckham and Jordan (2007). This methodology implies definition of a stream threshold area (i.e. the number of upstream grid cells capable to generate watercourse) and drainage network delineation using the D8 method (Pedrera et al., 2009 with reference therein). The validity of our DEM-derived drainage network and drainage basins was cross-checked visually using $1: 25,000$ scale topo- 

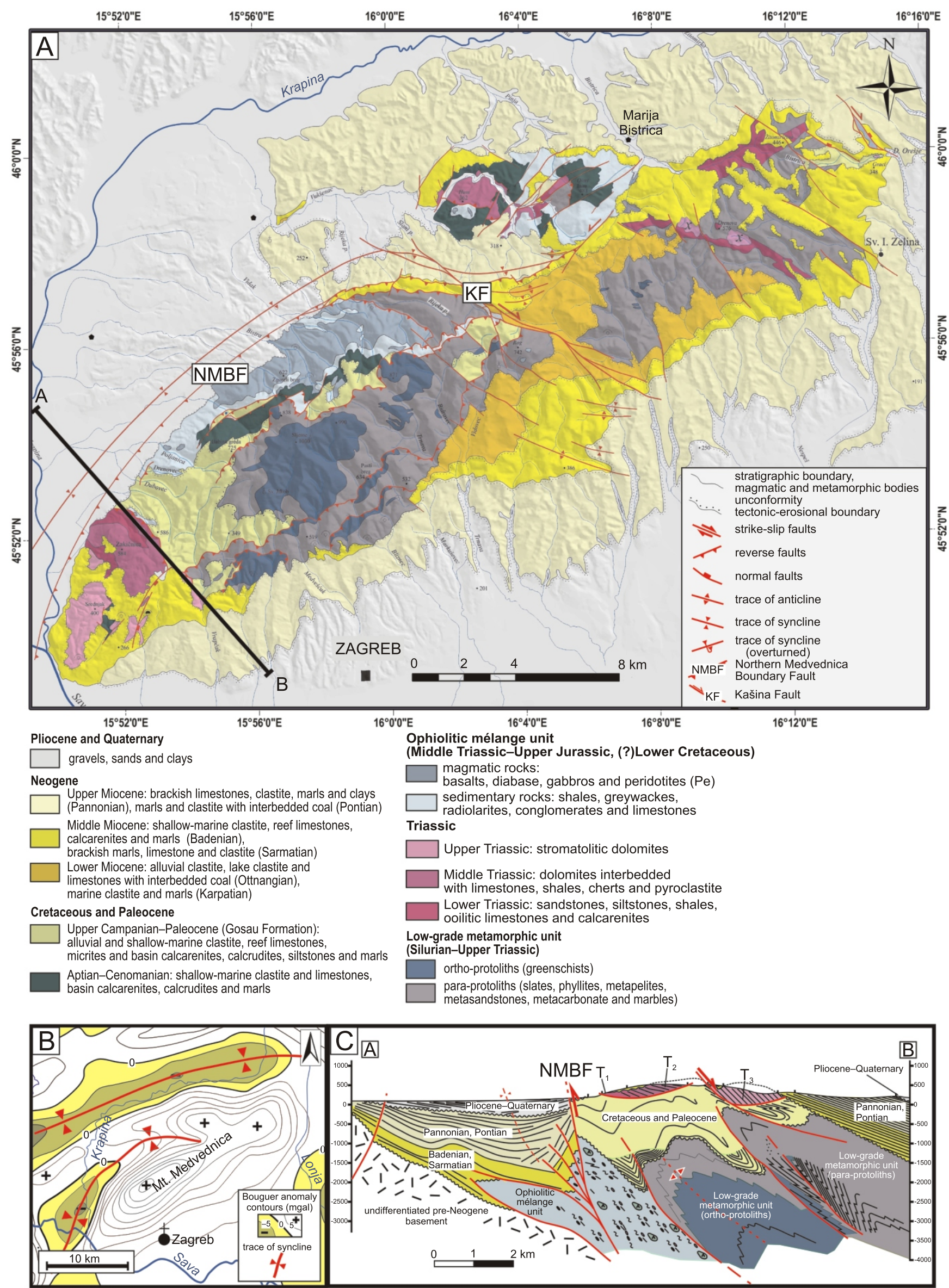


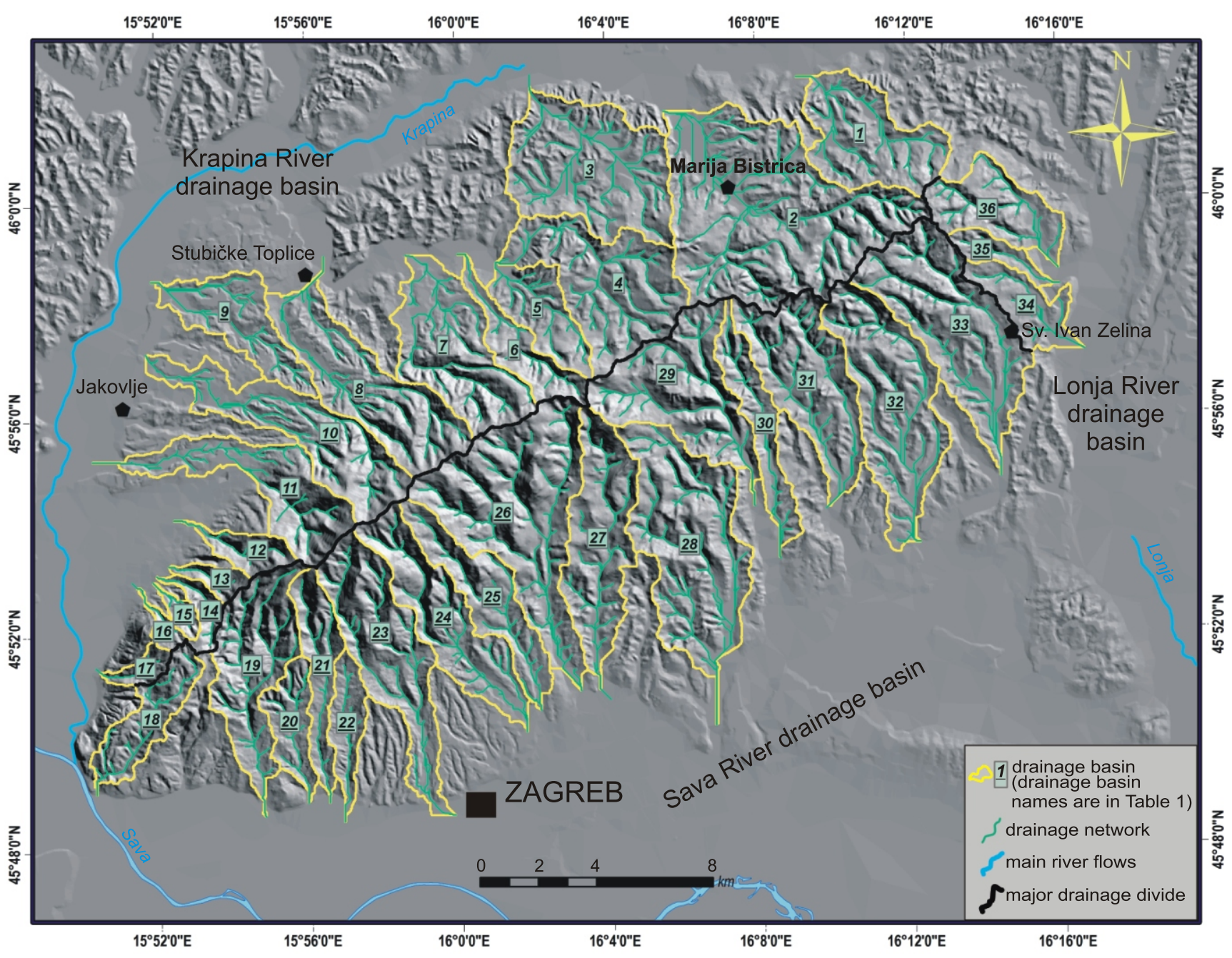

Fig. 3. A $25 \mathrm{~m}$ resolution DEM with hillshade overlay of Mt. Medvednica with indicated main river flows and 36 delineated drainage basins used for morphometric study (see Table 1 for names of drainage basins)

graphic maps. We delineated 36 drainage basins with outlet points located at the Mt. Medvednica mountain front (Fig. 3).

\section{SPATIAL ELEVATION AND SLOPE ANGLE DISTRIBUTION}

Elevation distribution is a foundational parameter for almost all DEM-based morphometric analyses. Elevation differences and elevation gradients, which convey signals of substrate lithology, climate conditions and of possible tectonic movements, were analysed with ESRI ArcMap software using Spatial Analyst extension. Two rasters of (1) local relief $\left(h_{\max }-h_{\min }\right.$ values, Fig. 4A) and (2) slope angle variability (refers to difference between maximum and minimum slope angle within certain area, Fig. 5) were extracted by the Neighbourhood Statistics method (with circular sampling window of $300 \mathrm{~m}$ radius), described in Ruszkiczay-Rüdiger et al. (2009).
Our map of local relief values (Fig. 4A and Table 1) indicates an uneven distribution: the SW area is characterized by more variable local relief values between 185 and $914 \mathrm{~m}$, while local relief values in the NE area range between 280 and $560 \mathrm{~m}$. The boundary zone between these two areas corresponds with the NW-striking Kašina Fault zone (Fig. 4B).

Slope angles vary between 0 and $51^{\circ}$ (Fig. 5A and Table 1). Values are mostly uniformly distributed, with $9 \%$ of hillslopes characterized by values greater than $25^{\circ}, 73 \%$ between 5 and $25^{\circ}$, and $18 \%$ between 0 and $5^{\circ}$. Comparison of the slope variability map and geological units (Fig. 5B) shows that higher slope angle values $\left(>20^{\circ}\right)$ correlate with more resistant pre-Neogene rocks, especially in the area covered by Triassic carbonates. The most extreme high slope angles (avg. max. $\left.40.67^{\circ}\right)$ occur within a very narrow zone $(<180 \mathrm{~m}$ wide) in the SW corner of Mt. Medvednica and along the foothills close to Stubičke Toplice. Subsequently, areas composed of less resis-

Fig. 2A - geological map of Mt. Medvednica (compiled and simplified by Tomljenović, 2002 after Šikić et al., 1978; Basch, 1981; Šimunić et al., 1983; Tomljenović, 1995; Halamić, 1998) projected onto the 25 m resolution DEM, note the lithological heterogeneity of exposed rocks and distribution of faults used here for subdivision of the study area; B - Bouguer gravity anomaly map of Aljinović (published in Verbič, 2005), anomaly map indicates a sharp transition from a positive (Medvednica antiform) into a negative gravity anomaly located in front of the southwestern termination of the mountain; C - geological profile in SW corner of Mt. Medvednica (after Tomljenović, 2002), note a vertical offset of Miocene-Quaternary sediments of ca. $3500 \mathrm{~m}$ on the NMBF 

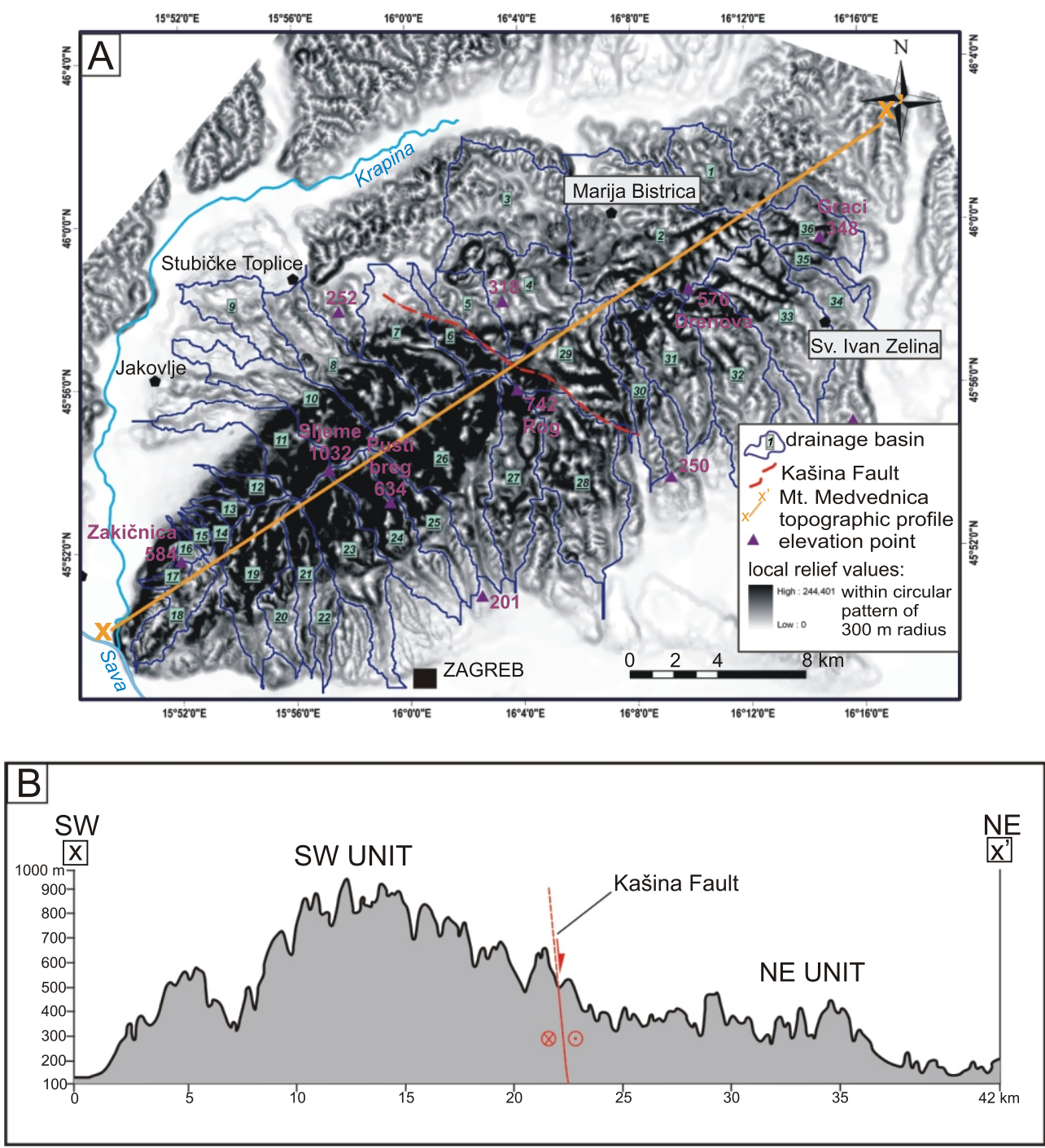

Fig. 4A - local relief map of Mt. Medvednica with elevation values calculated within circular window of $\mathbf{3 0 0} \mathrm{m}$ using Neighborhood Statistics, note the difference in local relief values between the SW and NE areas of the mountain; B - SW-NE-striking topographic profile of Mt. Medvednica (profile location indicated on Fig. 4A), note the correlation between the location of the Kašina Fault and abrupt elevation differences between the SW and NE parts of the mountain

Other explanations as in Figure 3

tant rocks of Miocene and Pliocene-Quaternary age were characterized by low slope angle values.

Based on combination of (1) morphometric criteria that accounts for differences in local relief and slope angle values, and (2) geological criteria that accounts for differences in lithology and structural characteristics, the study area is subdivided into two geomorphic areas, i.e. the SW and the NE area, which correspond to the footwall and the hangingwall of the Kašina Fault zone, respectively (Figs. 2 and 4). The SW area comprises 23 and the NE area 13 drainage basins (Fig. 3).

\section{HYPSOMETRIC CURVES}

Basin hypsometric curves indicate the distribution of basin surface areas or landmass below or above a certain surface datum (Strahler, 1952; Pérez-Peńa et al., 2009). Hence, the de- rived shape of hypsometric curves gives information about the volume of original basin remains, and indicates an erosional stage of drainage basins as outcome of interaction between tectonic activity, lithological heterogeneity and climatic conditions (Willgoose and Hancock, 1998; Huang and Niemann, 2006).

Keller and Pinter (2002) suggested that hypsometric curves can be used for comparing drainage basins of different size and can be used to separate phases in landscape evolution. According to Strahler (1952), convex hypsometric curves represent young and slightly eroded areas, while S- and concave-shaped curves characterize moderately to highly eroded areas, i.e. areas in mature and final (old) erosional stages (see also Pedrera et al., 2009; Pérez-Peńa et al., 2009 with references therein). Shapes of hypsometric curves are approximated by hypsometric integral $\left(H_{i}\right)$, known as the area below the hypsometric curve: 
Delineated drainage basins with extrapolated morphometric parameters

\begin{tabular}{|c|c|c|c|c|c|c|c|c|c|c|}
\hline \multirow{2}{*}{ No. } & \multirow{2}{*}{ Drainage basin } & \multirow{2}{*}{$\begin{array}{l}\text { Area } \\
{\left[\mathrm{km}^{2}\right]}\end{array}$} & \multirow{2}{*}{$\begin{array}{c}L \\
{[\mathrm{~km}]}\end{array}$} & \multicolumn{2}{|c|}{ Elevation [m] } & \multirow{2}{*}{$\begin{array}{l}\text { Local relief } \\
{[\mathrm{m}]}\end{array}$} & \multirow{2}{*}{$\begin{array}{l}\text { Maximum } \\
\text { slope }\left[{ }^{\circ}\right]\end{array}$} & \multirow{2}{*}{$\begin{array}{l}\text { Average } \\
\text { slope }\left[^{\circ}\right]\end{array}$} & \multirow{2}{*}{$H_{i}$} & \multirow{2}{*}{$A F$} \\
\hline & & & & $\min$. & $\max$. & & & & & \\
\hline 1 & Žitomirka & 13.73 & 6.96 & 165.0 & 445.39 & 280.39 & 35.18 & 10.15 & 0.26 & 16.53 \\
\hline 2 & Bistrica & 40.31 & 11.23 & 160.0 & 575.63 & 415.63 & 44.58 & 12.06 & 0.33 & 1.62 \\
\hline 3 & Pinja & 21.81 & 8.27 & 160.0 & 480.0 & 320.0 & 32.85 & 8.98 & 0.17 & 15.49 \\
\hline 4 & Burnjak & 18.85 & 9.14 & 196.44 & 610.0 & 413.56 & 37.87 & 11.39 & 0.28 & 18.01 \\
\hline 5 & Gornja Stubica & 7.32 & 5.45 & 195.46 & 630.0 & 434.54 & 34.58 & 11.27 & 0.27 & 16.07 \\
\hline 6 & Slani potok & 6.12 & 7.49 & 190.0 & 716.08 & 526.08 & 40.63 & 15.45 & 0.43 & 17.52 \\
\hline 7 & Rijeka & 16.3 & 10.47 & 180.0 & 833.98 & 653.98 & 45.58 & 13.51 & 0.32 & 5.4 \\
\hline 8 & Vidak & 17.66 & 11.85 & 160.0 & 890.0 & 730.0 & 50.8 & 13.38 & 0.32 & 7.82 \\
\hline 9 & Jamno & 9.71 & 7.22 & 140.0 & 325.0 & 185.0 & 28.36 & 6.28 & 0.3 & 12.45 \\
\hline 10 & Bistra & 16.13 & 12.11 & 150.0 & 1017.1 & 867.11 & 43.44 & 12.99 & 0.31 & 20.04 \\
\hline 11 & Dedina & 13.27 & 10.23 & 135.0 & 1031.3 & 896.33 & 44.33 & 14.4 & 0.33 & 0.06 \\
\hline 12 & Poljanica & 3.32 & 4.57 & 159.46 & 810.0 & 650.54 & 39.24 & 19.38 & 0.48 & 2.36 \\
\hline 13 & Dubovec & 1.83 & 2.77 & 180.0 & 584.83 & 404.83 & 40.93 & 18.53 & 0.46 & 3.53 \\
\hline 14 & Novačak & 2.33 & 3.81 & 170.77 & 585.0 & 414.23 & 41.75 & 19.61 & 0.49 & 6.27 \\
\hline 15 & Volovec & 1.24 & 2.23 & 165.12 & 585.0 & 419.88 & 39.48 & 18.29 & 0.54 & 6.01 \\
\hline 16 & Jablanovec & 1.15 & 2.6 & 150.0 & 600.0 & 450.0 & 40.48 & 15.37 & 0.69 & 5.16 \\
\hline 17 & Ivanšćak & 1.74 & 2.67 & 140.45 & 600.0 & 459.55 & 41.19 & 18.54 & 0.54 & 7.44 \\
\hline 18 & Bizeki & 7.01 & 7.36 & 130.24 & 600.0 & 469.76 & 40.34 & 13.32 & 0.48 & 17.99 \\
\hline 19 & Vrapčak & 14.58 & 10.31 & 127.87 & 860.0 & 732.13 & 44.12 & 18.21 & 0.35 & 12.8 \\
\hline 20 & Kustošija & 5.38 & 5.24 & 130.0 & 515.0 & 385.0 & 43.74 & 12.74 & 0.32 & 15.5 \\
\hline 21 & Veliki potok & 7.15 & 8.72 & 128.32 & 870.0 & 741.68 & 43.69 & 16.73 & 0.37 & 8.31 \\
\hline 22 & Kunišćak & 4.65 & 5.82 & 123.46 & 460.0 & 336.54 & 31.88 & 10.45 & 0.32 & 2.06 \\
\hline 23 & Medveščak & 17.21 & 12.21 & 116.29 & 1030.0 & 913.71 & 41.6 & 15.36 & 0.33 & 21.41 \\
\hline 24 & Bliznec & 14.19 & 10.49 & 150.0 & 1030.7 & 880.7 & 43.86 & 15.18 & 0.31 & 6.39 \\
\hline 25 & Štefanovec & 10.38 & 9.58 & 152.25 & 985.0 & 832.75 & 39.22 & 13.39 & 0.29 & 5.68 \\
\hline 26 & Trnava & 27.92 & 10.72 & 151.07 & 961.46 & 810.39 & 48.5 & 16.52 & 0.4 & 29.07 \\
\hline 27 & Čučerje & 15.52 & 11.18 & 150.0 & 740.41 & 590.41 & 39.26 & 13.59 & 0.28 & 3.69 \\
\hline 28 & Kostanić & 24.6 & 12.81 & 130.0 & 700.0 & 570.0 & 39.42 & 12.51 & 0.23 & 28.45 \\
\hline 29 & Kašina & 17.67 & 8.34 & 180.0 & 740.59 & 560.59 & 43.35 & 14.89 & 0.33 & 22.68 \\
\hline 30 & Blaguša & 7.45 & 9.26 & 160.0 & 490.15 & 330.15 & 43.16 & 12.77 & 0.35 & 6.34 \\
\hline 31 & Glavinčica & 16.36 & 8.67 & 150.0 & 543.53 & 393.53 & 44.35 & 13.19 & 0.33 & 25.78 \\
\hline 32 & Nespeš & 20.11 & 11.21 & 125.44 & 570.0 & 444.56 & 40.81 & 10.77 & 0.26 & 20.73 \\
\hline 33 & Zelina & 21.76 & 11.28 & 140.0 & 555.93 & 415.93 & 42.21 & 11.22 & 0.33 & 4.02 \\
\hline 34 & Topličica & 6.03 & 5.39 & 121.41 & 371.54 & 250.13 & 32.07 & 7.03 & 0.25 & 9.64 \\
\hline 35 & Kalinec & 2.72 & 4.13 & 130.0 & 474.83 & 344.83 & 36.84 & 12.38 & 0.41 & 0.1 \\
\hline 36 & Orešćak & 9.35 & 6.12 & 130.08 & 476.66 & 346.58 & 43.14 & 11.64 & 0.4 & 16.18 \\
\hline \multicolumn{2}{|c|}{ mean value } & 12.3 & 8.0 & 150.67 & 674.87 & 524.2 & 40.63 & 13.65 & 0.36 & 11.63 \\
\hline
\end{tabular}

$A F$ - asymmetry factor (see text for details), $H_{i}$ - hypsometric integral, $L$ - stream channel

$$
H_{i}=\frac{h_{\text {mean }}-h_{\text {min. }}}{h_{\text {max. }}-h_{\text {min. }}}
$$

where: $h_{\text {mean }}$ - average value of surface heights in drainage area $h_{\min }$ and $h_{\max }$ - minimal and maximal values of surface heights in drainage area, respectively.

Values of $H_{i}$ closer to 1 are typical for young erosional stage areas, and values closer to 0 are specific for mature or final (old) erosional stage areas (Strahler, 1952; Keller and Pinter, 2002; Pérez-Peńa et al., 2009; Ruszkiczay-Rüdiger et al., 2009). According to Ruszkiczay-Rüdiger et al. (2009), the high values of $H_{i}$ are addressed to erosional processes associated with dissected fluvial areas, while low values of $H_{i}$ are common in areas with prevailing deflation and fluvial aggradation processes.

In drawing hypsometric curves and computing hypsometric integral values for the drainage basins, we used CalHypso extension developed for ESRI ArcMap software (for details see Pérez-Peńa et al., 2009).

Hypsometric integral values and hypsometric curves for our 36 drainage basins are shown in Figure 6 and Table 1. Based on calculated values, we differentiated two groups of drainage basins: the first group comprises drainage basins with $H_{i}$ values ranging between 0.17 and 0.37 (drainage basins nos.: 1-5, $7-11,19-25,27-34)$, and the second one with $H_{i}$ values in the range between 0.40 and 0.69 (drainage basins nos.: 6, 12-18, $26,35,36)$. Very smooth concave-shaped hypsometric curves 

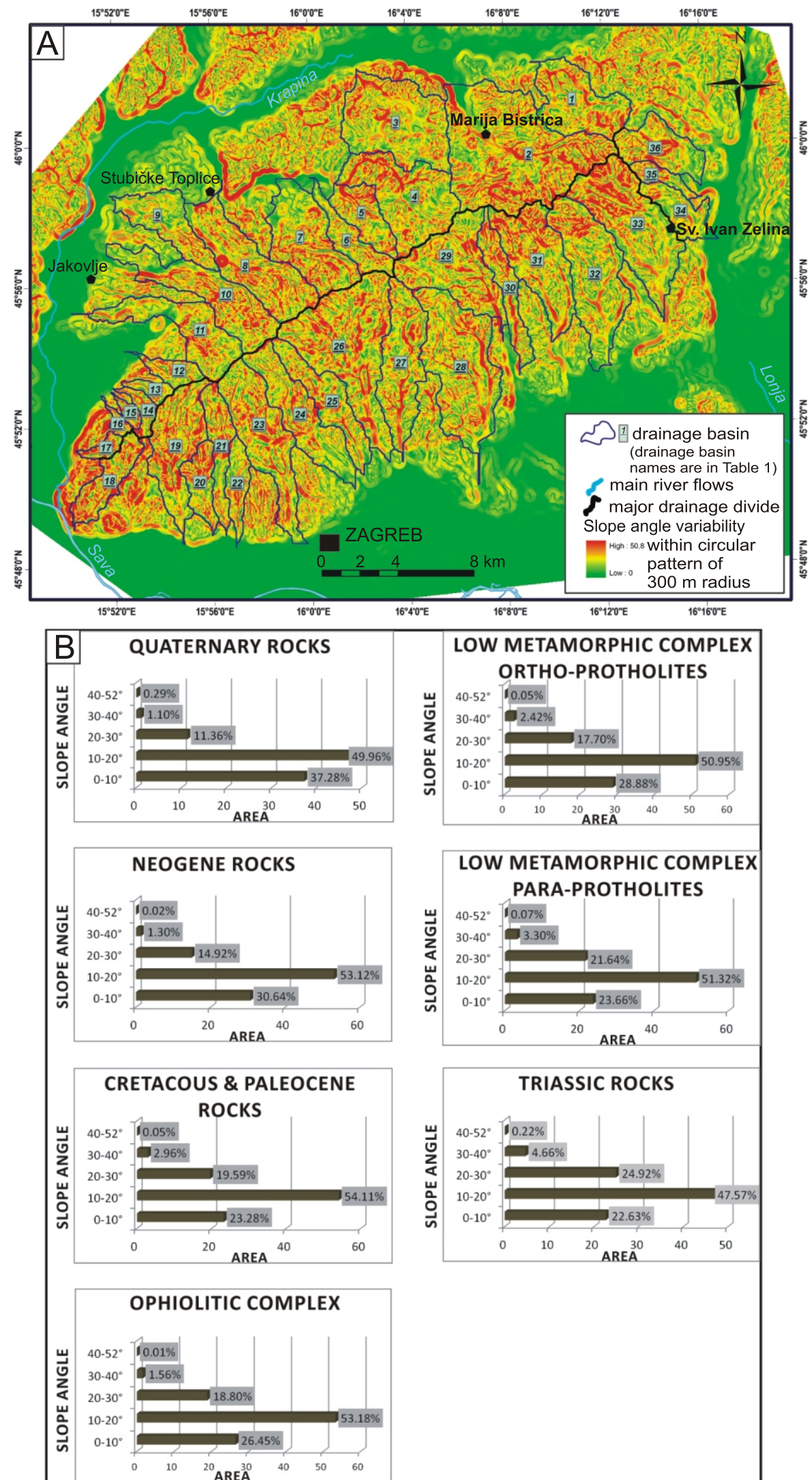

Fig. 5A - slope variability map of Mt. Medvednica with spatial distribution of slope angle values $\left({ }^{\circ}\right)$ calculated within circular window with a radius of $300 \mathrm{~m}$ using Spatial Analyst/Surface Analysis and Neighborhood Statistics; B - cumulative slope angle histogram per each lithological unit in Mt. Medvednica, note that total percentage of higher slope angle value $\left(>20^{\circ}\right)$ is greater within "more resistant" pre-Neogene rocks 

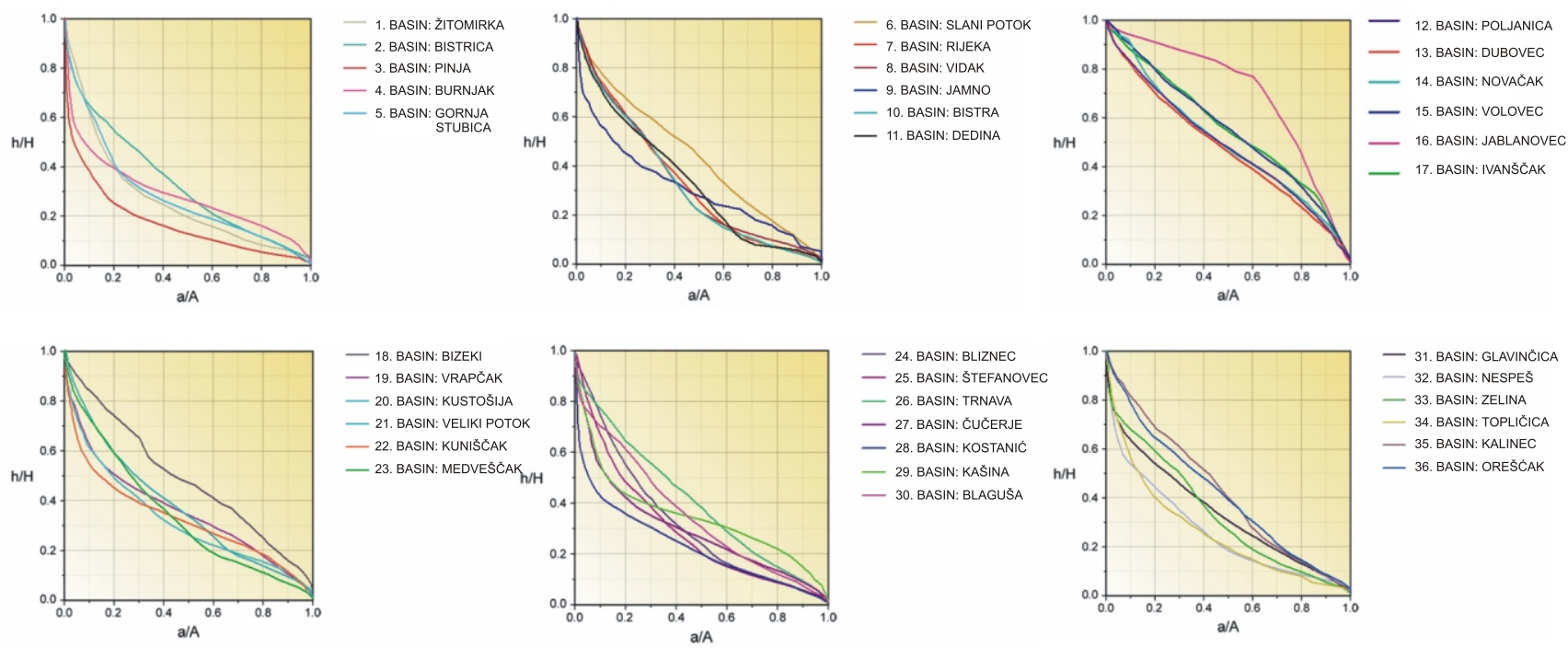

Fig. 6. Hypsometric curves for 36 delineated drainage basins of Mt. Medvednica

Hypsometric curves have been grouped sequentially considering (1) NW slopes (from NE to SW, drainage basins nos.1-17), and (2) SE slopes (from SW to NE, drainage basins nos.18-36); computation was based on a $25 \mathrm{~m}$ DEM and CalHypso extension (see Pérez-Pena et al., 2009)

are characteristic for the first group, while convex-shaped hypsometric curves are characteristic for the second group.

Qualitative comparison of the shapes of hypsometric curves shows no major differences between drainage basins on the NW and SE slopes of Mt. Medvednica (Fig. 6), with prevalence of concave shapes in the ne area of Mt. medvednica (drainage basins nos.: 1-5) where hypsometric curves are "the most concave". Exceptions from concave shapes are "the most convex" shapes of drainage basins nos. 6 and 12-18, which are located in the SW area of Mt. Medvednica (Fig. 6). The differences in hypsometric curve shapes are confirmed with $H_{i}$ values which range between 0.17 (smooth, low elevation landscape) and 0.69 (highly dissected landscape).

To discriminate the basins with relative uplift from the basins with relative subsidence, we used a scatter plot of $H_{i}$ values in relation to average slope values (Fig. 7) as proposed by Ruszkiczay-Rüdiger et al. (2009). In Figure 7, three clusters could be distinguished. $H_{i} 1$ cluster (drainage basins nos.: 9,34 and 3 ) is associated with low average slope values $\left(7.43^{\circ}\right)$ and low $H_{i}$ values $(0.24)$, which indicates low values of uplift rates and a likely predominance of accumulation processes. Drainage basins from this cluster are positioned in the NE area of Mt. Medvednica. The second cluster, $H_{i}$ (drainage basins nos.: 1 , $2,4-11,18-33,35,36)$ represents drainage basins with average slope values of $13.31^{\circ}$ and intermediate $H_{i}$ values (0.33) Such basins are dominantly located in the central part of Mt. Medvednica. The third $H_{3} 3$ cluster (drainage basins nos.: 12-17) comprises drainage basins with dissected landscape having both high average slope $\left(18.29^{\circ}\right)$ and high $H_{i}$ values (0.53), which correlate with high differential uplift rates and probable predominance of erosional processes. Drainage basins belonging to $\mathrm{H}_{3} 3$ cluster encompass the SW corner of Mt. Medvednica. Those basins are in a relatively young erosional stage of landscape evolution where deep incision and rugged terrain features prevail, which may be driven by the ongoing tectonic activity and uplift.

\section{ASYMMETRY FACTOR}

To answer the question on possible tectonic block tilting we followed the procedure of asymmetry factor $(A F)$ extraction proposed by Keller and Pinter (2002) and Pérez-Peńa et al. (2010). According to these authors, the asymmetry factor is defined as:

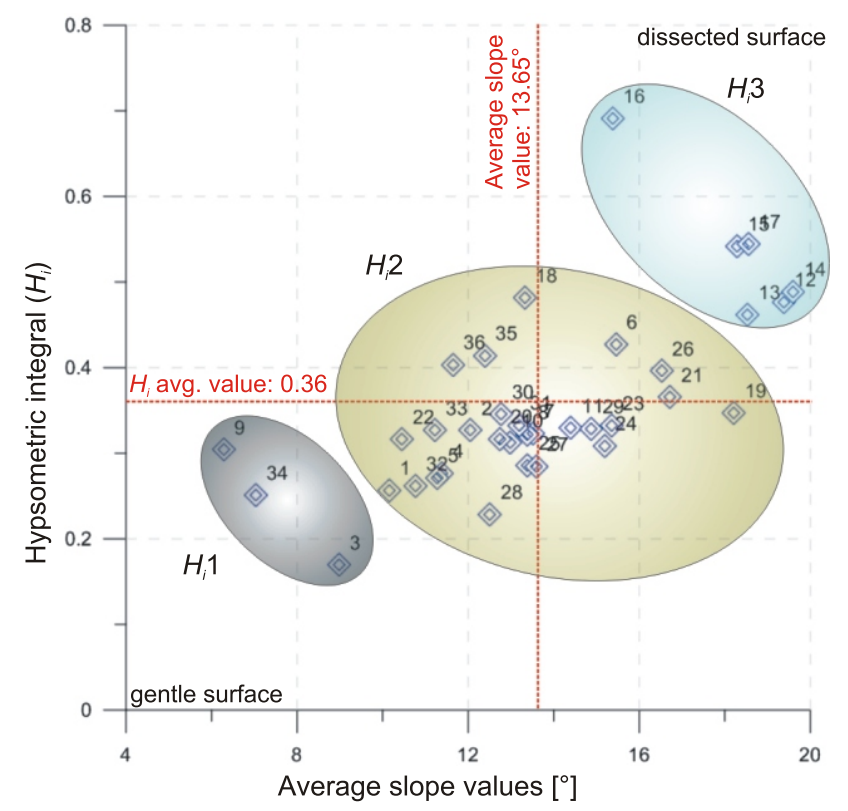

Fig. 7. Scatter plot of average slope and $\mathrm{Hi}$ values

Drainage basins are clustered in three groups $\left(H_{i} 1, H_{i} 2\right.$ and $\left.H_{i} 3\right)$; higher values of $H_{i}$ and average slopes indicate more dissected surfaces and their younger erosional stage (see Table 1 for drainage basin names, $H_{i}$ and average slope values) 


$$
A F=\frac{A_{R}}{A_{T}} \times 100
$$

where: $A_{R}$ - the area of delineated drainage basin to the right (facing downstream) of the main stream, $A_{T}$ - the total area of drainage ba$\sin$.

$A F$ values, greater or lower than 50 , indicate asymmetry of drainage basin. Additionally, we used the modified definition of $A F$ :

$$
A F=\left|50-A_{R} \times 100 / A_{T}\right|
$$

proposed by Pérez-Peńa et al. (2010), according to which the drainage basins are classified as symmetric $(A F<5)$, gently asymmetric $(A F=5-10)$, moderately asymmetric $(A F=10-15)$, and strongly asymmetric $(A F>15)$.

The $A F$ values calculated for the drainage basins range between 0.06 and 29.7 (Table 1). Spatial distribution of $A F$ values, with arrows indicating the asymmetry direction sense, is shown in Figure 8. The asymmetry direction arrows indicate the preferred asymmetry sense on both hill slopes divided by several transition zones. Transitional zones are delineated as boundaries between drainage basins with high $A F$ values and the opposite basin asymmetry direction senses perpendicular to the stream channel (Fig. 8). The first prominent transition zone runs between drainage basins no. $31(A F=25.78)$ and 29
$(A F=22.68)$ and continues NW-ward into the boundary between drainage basins no. $3(A F=15.49)$ and no. 4 $(A F=18.01)$. Immediately to the $\mathrm{W}$ of it, the second prominent transition zone separates drainage basins no. $29(A F=22.68)$ and no. $28(A F=28.45$, no. $28(A F=28.45)$ and no. 26 $(A F=29.07)$ and eventually basins no. $4(A F=18.01)$ and no. 5 $(A F=16.07)$. Differences in $A F$ values and asymmetry direction senses are observed in two additional although less prominent transition zones: between drainage basins no. $36(A F=16.18)$ and no. $1(A F=16.53)$, and drainage basins no. $23(A F=21.41)$ and no. $20(A F=15.50)$. These transition zones might be explained by (1) possible structural control of underlying bedrock fabric due to orientation of bedding and schistosity forcing migration of streams in preferable down-dip direction or/and by (2) structural discontinuities, e.g. faults or fracture systems, similar to the effects of those described in southern Spain by Hamdouni et al. (2008).

In other parts of the Mt. Medvednica range, drainage basin asymmetry is unidirectional and ranges from symmetric to gently asymmetric, which implies the absence of major surface tilting in these parts.

\section{LONGITUDINAL STREAM PROFILES}

Shape of longitudinal stream profiles has been subject of many prolific geomorphologic studies during the second half of last century (Rădoane et al., 2003). These profiles were con-

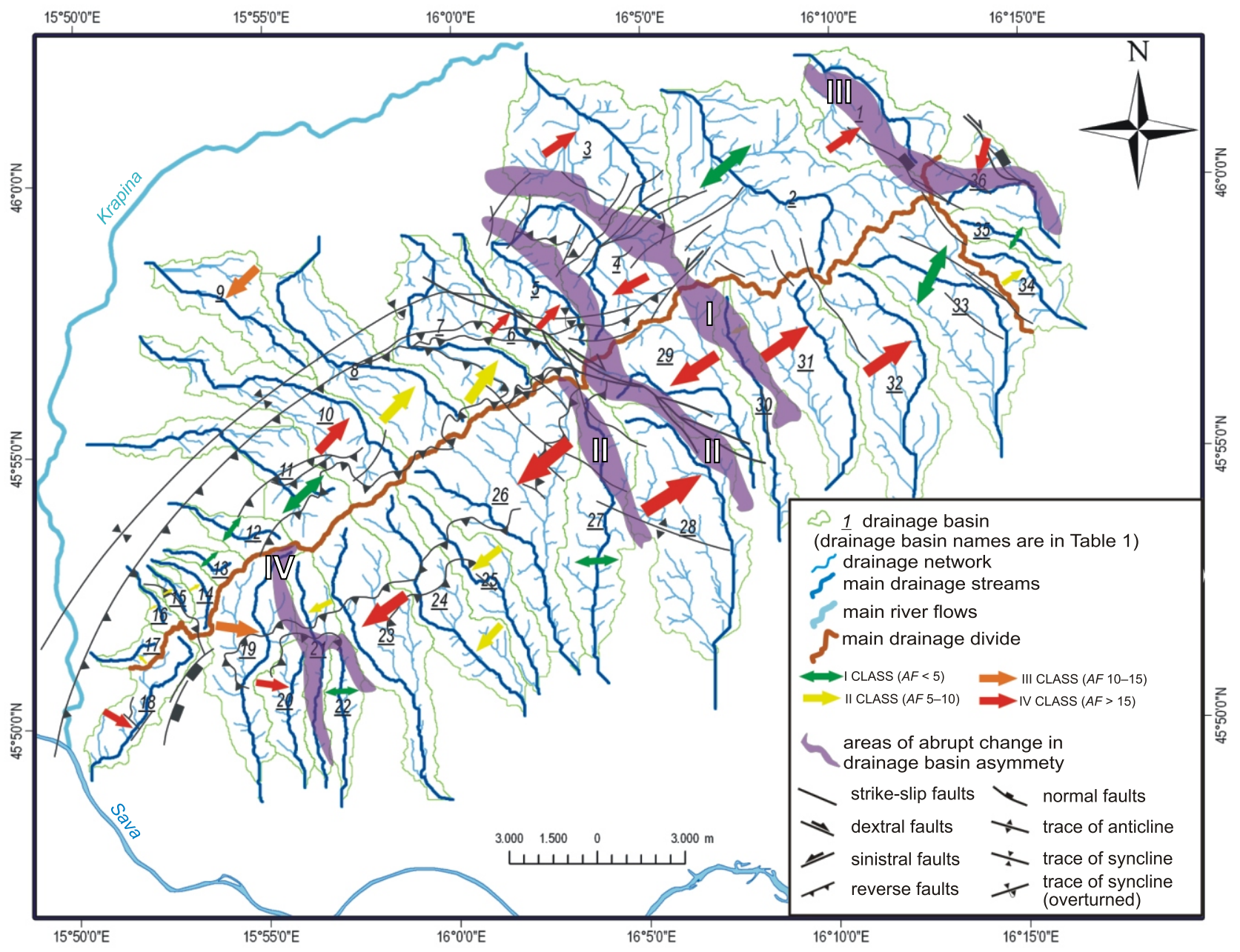

Fig. 8. Asymmetry factor (AF) distribution map for delineated drainage basins in Mt. Medvednica

$A F$ values are colour-coded, and asymmetry directions sense is indicated by arrows; map also indicates zones of abrupt change in basin asymmetry direction sense 
structed by plotting the values of altitude in relation to the stream lengths, and represent equilibrium between bedrock erosion and tectonic uplift (Schumm et al., 2000; Pérez-Peńa et al., 2010 and references therein). According to Snow and Singerland (1987) and Ruszkiczay-Rüdiger et al. (2009), the shape of longitudinal profiles in the absence of active tectonics becomes more concave along the channel, which is in correlation with stream age. Any deviation of longitudinal stream profile from the stream equilibrium profile (i.e., concave profile represents long-term equilibrium balance between climatic conditions, uplift rate and erosional processes) suggests the presence of resistant channel bedrock or tectonic activity along the course (Rădoane et al., 2003; Pérez-Peńa et al., 2010). Therefore, if erosional processes prevail, longitudinal profiles become more "concave-convex", while convex profiles occur in tectonically active areas or in highly resistant channel bedrock (Pérez-Peńa et al., 2010).

In the Mt. Medvednica area, statistical parameters of normalized longitudinal stream profiles were used for morphometric comparison between delineated drainage basins. Normalized longitudinal stream profiles were used in order to make direct comparison between streams with different lengths and absolute elevation gradients. Following the procedure described in Demoulin (1998) and Ruszkiczay-Rüdiger et al. (2009), we normalized distance values along the streams to the total length of the streams $(I / L)$, and elevation values to the absolute elevation gradients along the streams $(e / E)$. To estimate which stream profiles are closer to equilibrium profile, we computed the following statistical parameters (Table 2): concavity factor $\left(C_{f}\right)$, maximal concavity $\left(C_{\text {max. }}\right)$ and distance from the source $(\Delta / / L)$.

In addition, we investigated the connection between the shape of the longitudinal stream profiles, the contributing drainage basins area and the possible tectonic activity by calculating statistical values of channel steepness index $\left(k_{s}\right)$ and concavity index $(\theta)$. Channel steepness analysis presented and summarized by Wobus et al. (2006) and Whipple et. al. (2007) was utilized using software packages Matlab and ESRI ArcMap software with ArcHydro 1.1 extension and special geomorphologic extension StPro (Whipple et al., 2007).

Normalized longitudinal stream profiles. Deviations of the delineated stream profiles in relation to equilibrium profile (i.e. deviation of the graded profile) were analysed by parameters $C_{f}, C_{\max }$ and $\Delta / L$ (Fig. 9). $C_{f}$ values, which are expressed in the range between 0 and $100 \%$, actually corresponds to the plot area or "eroded area" between normalized stream profile and straight line that connects the stream source point with the mouth of the stream. The $C_{\max }$. parameter represents the normalized maximal elevation difference between stream profile and ideal straight line connecting the source point and the mouth of the stream, ranging from 0 and 1 . Ideally, the high $C$ values and $C_{\text {max. }}$ values closer to the stream source point are characteristic for concave-upward stream profiles that are closer to the ideal equilibrium profile (Demoulin, 1998; Rădoane et al., 2003; Ruszkiczay-Rüdiger et al., 2009). In the Mt. Medvednica area, the values of concavity factor are in the range between 16 and $67.8 \%$. The maximal concavity values vary between 0.17 and 0.63 , while its position or distance from the source is between 0.18 and 0.65 (Fig. 9 and Table 2).

An objective comparison between delineated drainage basins was achieved following the procedure described in Holbrook and Schumm (1999) and Ruszkiczay-Rüdiger et al. (2009), using a scatter plot correlation between values of $C_{\max }$ and $\Delta / / L$ parameters. We discriminate four clusters in our drainage system data (Fig. 10). Clusters P1 and P2 include drainage basins nos. 6 and $12-18$ with $C_{f}$ values ranging from 16 to $40 \%$, and with low values of $C_{\max }(0.173-0.318) . C_{\max }$ values of $\mathrm{P} 1$ and P2 clusters are positioned in the middle and in the middle upper sections of longitudinal stream profiles $(\Delta / / L$ values are between 0.418 and 0.653 ), respectively. As opposed to these, the streams clustered in P3 cluster (drainage basins nos. 2, 4-11, $13,17,19-36$ ) and P4 cluster (drainage basins nos. 1 and 3 ) show the characteristics closer to equilibrium conditions, with values of $C_{f}$ between 37.2 and $67.8 \%$, and $C_{\max }$. values between 0.344 and 0.627 closer to the source point $(\Delta / / L$ values are between 0.176 and 0.423 ).

Normalized channel steepness. The stream profile depicts proportion of the local stream channel gradient to upstream contributing drainage area. Described by the Flint's power-law function, the stream channel slope is expressed as follows (Hack, 1973; Flint, 1974; Howard and Kerby 1983; Whipple, 2004; Wobus et al., 2006):

$$
S=k_{S} A^{-\theta}
$$

where: $S$ - the main channel slope, $A$ - the upstream area of the contributing drainage basin, $\theta-$ concavity index, $k_{s}$ - channel steepness index.

The value of $\theta$ connects incision rate with channel steepness and reflects catchment hydrology with channel specific incision processes like plucking, macro-abrasion, wear, chemical and physical weathering and possible cavitations (Wobus et al., 2006 with references therein). In addition, the parameter of $k_{s}$ is also known as a function of rock uplift, lithology and climate, with higher values in areas of ongoing uplift. This relation is valid for streams that are in dynamic equilibrium state, meaning that the rate of erosion is in balance with the rate of uplift (Snyder et al., 2000).

Power law-relation [5] between the upstream area of drainage basin and channel steepness must be taken with caution, since it is not valid for the uppermost part of stream channel because the critical drainage area is smaller than $1 \mathrm{~km}^{2}$ and therefore debris flows may have significant role in sculpturing the channel profile. Also, problematic is the lower part of streams where the stream channel may traverse from a detachment or bedrock-limited to a transport-limited stream system where alluvial sedimentation predominates (Wobus et al., 2006).

In the log A-log S coordinate system, function [5] will plot as a line with a slope corresponding to the concavity index $\theta$, and with the $y$ axis intercept corresponding to the steepness index $k_{s}$ (Fig. 11). Direct comparison of possible ongoing rock uplift differences between stream profiles is usually done by normalized channel steepness index $-k_{s n}$. The $k_{s n}$ values are calculated by its normalization to upstream drainage area and reference concavity $\left(\theta_{\text {ref }}\right)$ and observed concavity $(\theta)$ difference (Wobus et al., 2006; Ismail and Abdsalam, 2012).

According to Ismail and Abdesalam (2012), the $k_{s n}$ value can be expressed by the equation:

$$
k_{s n}=k_{s} A^{\left(\theta_{r e f}-\theta\right)}
$$

where: $\theta_{\text {ref }}$ - reference concavity, $\theta$ - observed concavity of the stream profile; other explanations as in equation [5].

Usually, values of $k_{s}$ and for given dataset are fitted by the best regression model as free parameters for the certain stream segment, analysing slope-area data using function [5]. Successively, $k_{s n}$ values are determined for individual slope-area stream segments using $\theta_{\text {ref }}$ values (see Wobus et al., 2006; Cyr, 2010). Reference concavities, according to Wobus et al. (2006) 
Normalized longitudinal stream profile morphometric parameters

\begin{tabular}{|c|c|c|c|c|c|c|c|c|c|c|c|}
\hline No. & Drainage basin & $A g[\mathrm{~m}]$ & $C_{\max }$ & $\Delta / / L$ & $C_{f}[\%]$ & No. of KP & $\theta$ & $k_{s n}(\max )$. & $k_{s n}$ (avg.) & $k_{s n}(\min )$. & $\begin{array}{c}\theta \text { and } k_{\text {sn }} \\
\text { cluster }\end{array}$ \\
\hline 1 & Žitomirka & 225.00 & 0.63 & 0.22 & 67.80 & 0 & 0.77 & 38.46 & 15.40 & 2.59 & 2 \\
\hline 2 & Bistrica & 292.83 & 0.50 & 0.26 & 57.40 & 0 & 0.61 & 62.71 & 22.40 & 1.80 & 1 \\
\hline 3 & Pinja & 174.74 & 0.57 & 0.33 & 62.60 & 0 & 0.51 & 51.39 & 26.30 & 0.85 & 1 \\
\hline 4 & Burnjak & 236.72 & 0.47 & 0.29 & 54.20 & 0 & 0.73 & 24.74 & 25.50 & 3.20 & 2 \\
\hline 5 & Gornja Stubica & 314.82 & 0.40 & 0.27 & 48.20 & 0 & 0.76 & 57.69 & 28.80 & 11.89 & 2 \\
\hline 6 & Slani potok & 376.30 & 0.32 & 0.23 & 40.20 & 0 & 0.65 & 55.84 & 36.90 & 26.47 & 1 \\
\hline 7 & Rijeka & 480.27 & 0.38 & 0.39 & 40.40 & 0 & 1.30 & 102.35 & 47.60 & 14.00 & 4 \\
\hline 8 & Vidak & 600.00 & 0.43 & 0.29 & 52.80 & 1 & 1.30 & 89.03 & 46.65 & 12.93 & 4 \\
\hline 9 & Jamno & 110.00 & 0.35 & 0.29 & 37.20 & 0 & 0.63 & 21.31 & 10.10 & 10.13 & 1 \\
\hline 10 & Bistra & 658.94 & 0.49 & 0.24 & 57.20 & 1 & 1.65 & 147.78 & 49.10 & 21.14 & 4 \\
\hline 11 & Dedina & 561.46 & 0.47 & 0.32 & 58.80 & 1 & 1.05 & 115.03 & 64.50 & 11.68 & 4 \\
\hline 12 & Poljanica & 474.82 & 0.31 & 0.42 & 37.00 & 1 & 1.38 & 97.29 & 71.00 & 42.65 & 4 \\
\hline 13 & Dubovec & 238.74 & 0.27 & 0.27 & 30.00 & 0 & 0.87 & 57.88 & 41.30 & 26.92 & 2 \\
\hline 14 & Novačak & 249.99 & 0.17 & 0.51 & 19.00 & 1 & 0.60 & 48.15 & 35.90 & 24.55 & 1 \\
\hline 15 & Volovec & 320.37 & 0.23 & 0.43 & 27.00 & 2 & 0.99 & 67.03 & 51.55 & 36.73 & 2 \\
\hline 16 & Jablanovec & 385.81 & 0.29 & 0.44 & 30.60 & 1 & 1.86 & 120.39 & 87.90 & 16.30 & 4 \\
\hline 17 & Ivanšćak & 363.85 & 0.30 & 0.24 & 31.00 & 1 & 0.56 & 93.20 & 76.00 & 29.15 & 1 \\
\hline 18 & Bizeki & 418.59 & 0.20 & 0.65 & 16.00 & 2 & 1.36 & 116.77 & 43.47 & 12.00 & 4 \\
\hline 19 & Vrapčak & 602.65 & 0.39 & 0.34 & 46.60 & 4 & 0.77 & 74.96 & 39.77 & 26.44 & 2 \\
\hline 20 & Kustošija & 229.04 & 0.36 & 0.24 & 43.40 & 0 & 0.59 & 37.20 & 29.30 & 16.86 & 1 \\
\hline 21 & Veliki potok & 556.97 & 0.36 & 0.30 & 44.20 & 0 & 0.60 & 74.79 & 40.60 & 30.02 & 1 \\
\hline 22 & Kunišćak & 190.06 & 0.34 & 0.31 & 43.60 & 0 & 0.64 & 38.82 & 17.80 & 13.90 & 1 \\
\hline 23 & Medveščak & 721.05 & 0.39 & 0.36 & 48.40 & 2 & 1.36 & 112.02 & 56.71 & 18.44 & 4 \\
\hline 24 & Bliznec & 746.74 & 0.39 & 0.36 & 48.60 & 0 & 0.77 & 104.63 & 66.80 & 13.95 & 2 \\
\hline 25 & Štefanovec & 681.18 & 0.39 & 0.26 & 48.40 & 0 & 1.10 & 116.61 & 60.30 & 19.85 & 4 \\
\hline 26 & Trnava & 661.44 & 0.47 & 0.32 & 52.80 & 5 & 1.70 & 139.44 & 53.25 & 17.12 & 4 \\
\hline 27 & Čučerje & 423.28 & 0.40 & 0.21 & 49.60 & 0 & 0.76 & 66.33 & 36.30 & 13.88 & 2 \\
\hline 28 & Kostanić & 343.03 & 0.48 & 0.32 & 59.20 & 0 & 0.71 & 50.11 & 26.10 & 9.99 & 2 \\
\hline 29 & Kašina & 398.03 & 0.46 & 0.21 & 56.40 & 0 & 0.37 & 60.20 & 31.70 & 11.51 & 1 \\
\hline 30 & Blaguša & 217.78 & 0.35 & 0.28 & 38.60 & 3 & 0.76 & 35.25 & 24.30 & 4.01 & 2 \\
\hline 31 & Glavinčica & 245.25 & 0.38 & 0.37 & 47.60 & 3 & 1.28 & 46.31 & 21.54 & 13.59 & 3 \\
\hline 32 & Nespeš & 315.77 & 0.46 & 0.18 & 56.40 & 1 & 0.92 & 43.28 & 21.77 & 5.59 & 2 \\
\hline 33 & Zelina & 320.00 & 0.39 & 0.42 & 49.40 & 3 & 0.80 & 52.81 & 25.20 & 10.44 & 2 \\
\hline 34 & Topličica & 160.79 & 0.50 & 0.20 & 60.00 & 0 & 1.20 & 52.69 & 13.00 & 3.67 & 3 \\
\hline 35 & Kalinec & 239.02 & 0.40 & 0.31 & 42.20 & 0 & 1.20 & 64.11 & 31.50 & 17.88 & 3 \\
\hline 36 & Orešćak & 270.70 & 0.38 & 0.22 & 45.80 & 0 & 0.98 & 56.01 & 35.40 & 10.12 & 2 \\
\hline \multicolumn{2}{|c|}{ mean value } & 383.50 & 0.39 & 0.31 & 45.79 & 0.89 & 0.95 & 72.02 & 39.21 & 15.62 & - \\
\hline
\end{tabular}

$A g$ - absolute elevation gradient, $C_{f}$ - concavity factor, $C_{\text {max }}$ - maximal concavity, $\mathrm{KP}$ - knickpoint, $k_{s n}-$ normalized channel steepness index, $\Delta l / L$ - distance from the source, $\theta$ - concavity index

and Ismail and Abdesalam (2012), are usually in the range between 0.35 and 0.65 , reflecting stream channels free of knickpoints, fault activity or lithological heterogeneity averaged on a regional scale.

In our study, $k_{s n}$ values were computed with $\theta_{\text {ref }}$ value of 0.45 , following suggestion of Whipple (2004), which allowed us to compare the computed $k_{s n}$ values to the values collected in other studies (Whipple, 2004; Wobus et al., 2006; Cyr et al., 2010; Ismail and Abdelsalam, 2012).

In the Mt. Medvednica area, the principal obstacle in using this method for identification of ongoing uplifting sub-areas is a significant lithological heterogeneity within delineated drainage basins. However, we assumed the steady state of streams, because constant uplift rates during the Pliocene and Quaternary as well as evenly distributed erosional rates have been previously reported by Šimunić and Šimunić (1987) and Prelogović and Velić (1988).

We performed stream profile analysis of $k_{s n}$ and calculated concavity index $\theta$ values for each $200 \mathrm{~m}$ long stream segment in all delineated drainage basins (Fig. 12). Our main emphasis was on obtaining a general spatial distribution of $\theta$ values, max. $k_{s n}$ and average profile $k_{s n}$ values, and only to a lesser extent on detailed analysis of particular stream profile segments. Excluding short and steep parts of drainages influenced by debris 

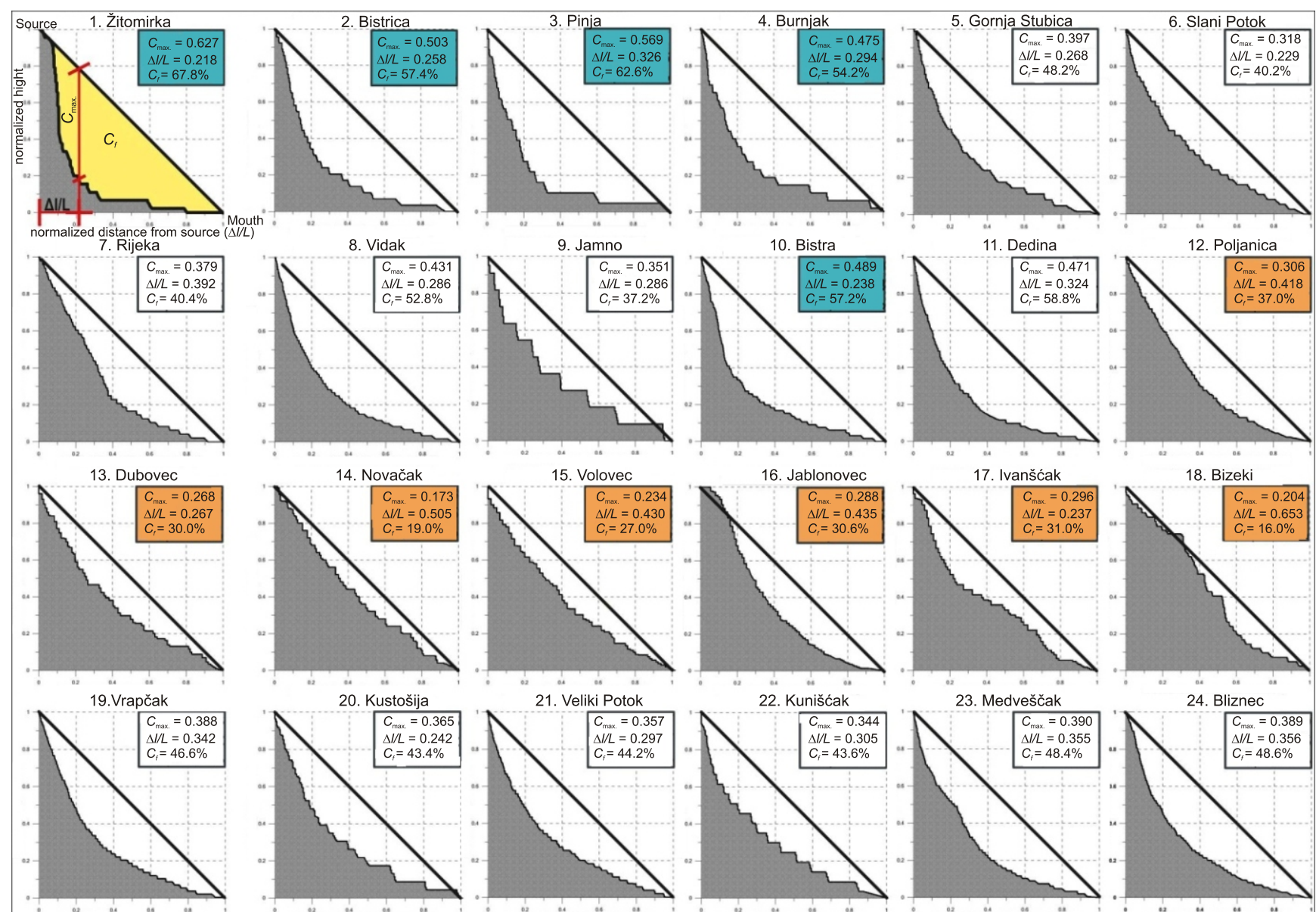

23. Medveščak
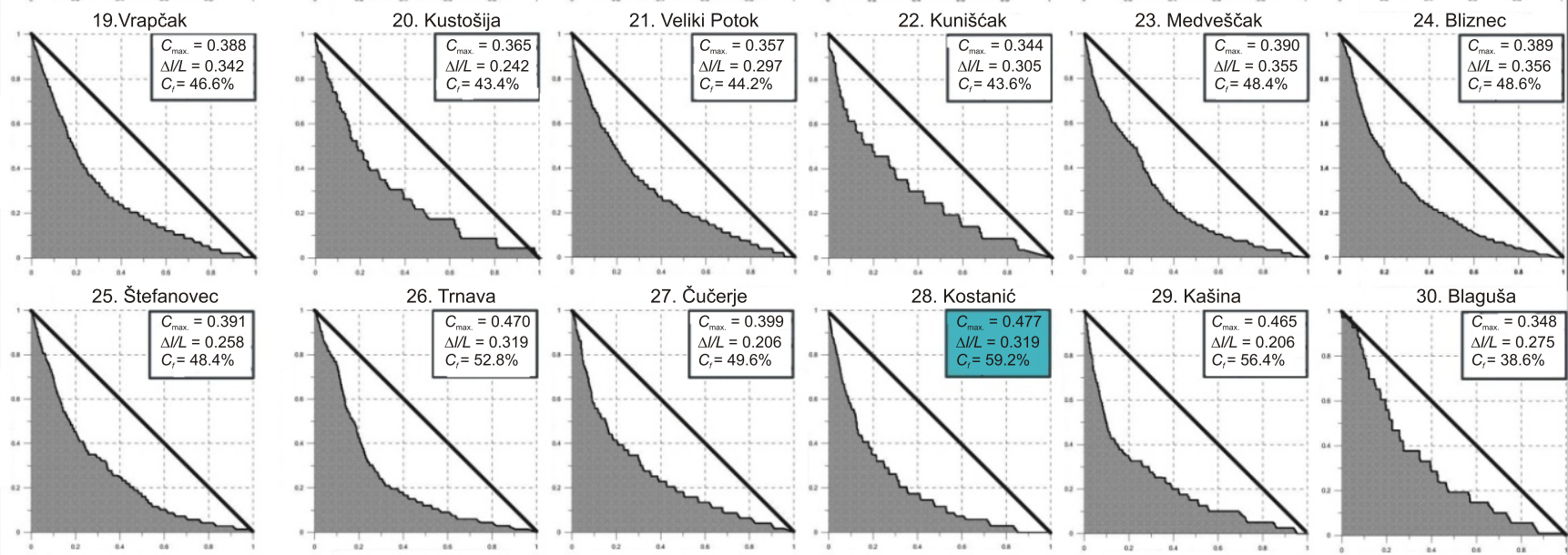

28. Kostanić

29. Kašina

30. Blaguša
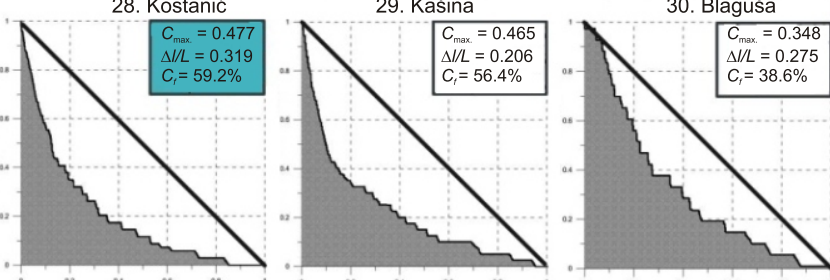

34. Topličica
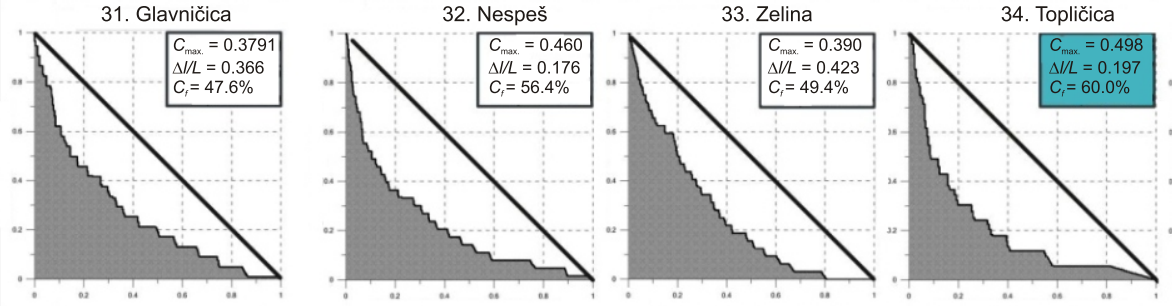

35. Kalinec

36. Orešćak
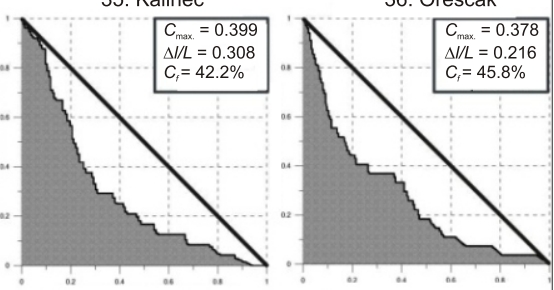

Fig. 9. Normalized longitudinal stream profiles

Calculated statistical parameters; concavity factor $\left(C_{f}\right)$, maximal concavity $\left(C_{\text {max. }}\right)$ and distance from the source $(\Delta / / L)$ are visualized on drainage basin no. 1 ; high values of $C_{f}$ and $C_{\text {max. }}$ and low $\Delta / / L$ values shown in blue indicate streams in a mature to old erosional stage, while orange statistical values indicate streams in a young erosional stage

flows (using the upstream area of less than $1 \mathrm{~km}^{2}$ as a criterion), stream profiles were classified into four groups using primarily observed concavity $\theta$ values (Fig. 12) proposed by Whipple (2004) in combination with calculated average profile $k_{s n}$ values (Table 2 ).

The first group of basins, characterized by low and moderate values of $\theta(0.0-0.7)$ and by predominantly moderate average $k_{s n}$ values in the range of $10.1-76.0$, comprises drainage basins nos. 2, 3, 6, 9, 14, 17, 20-22 and 29. In this group, the streams have concave longitudinal stream profiles without corrugations and with only a few minor knickpoints. The second group of basins, including drainage basins nos. 1, 4, 5, 13, 15, $19,24,27,28,30,32,33$ and 36 , is characterized by high $\theta$ values $(0.701-1.0)$ and moderate average $k_{s n}$ values in the range between 15.4 and 66.8. In this group, knickpoints occur more frequently along longitudinal profiles. The third group includes basins nos. 31, 34, 35 and was delineated by extremely high $\theta$ values (1.001-1.86) associated with multiple knickpoints and 


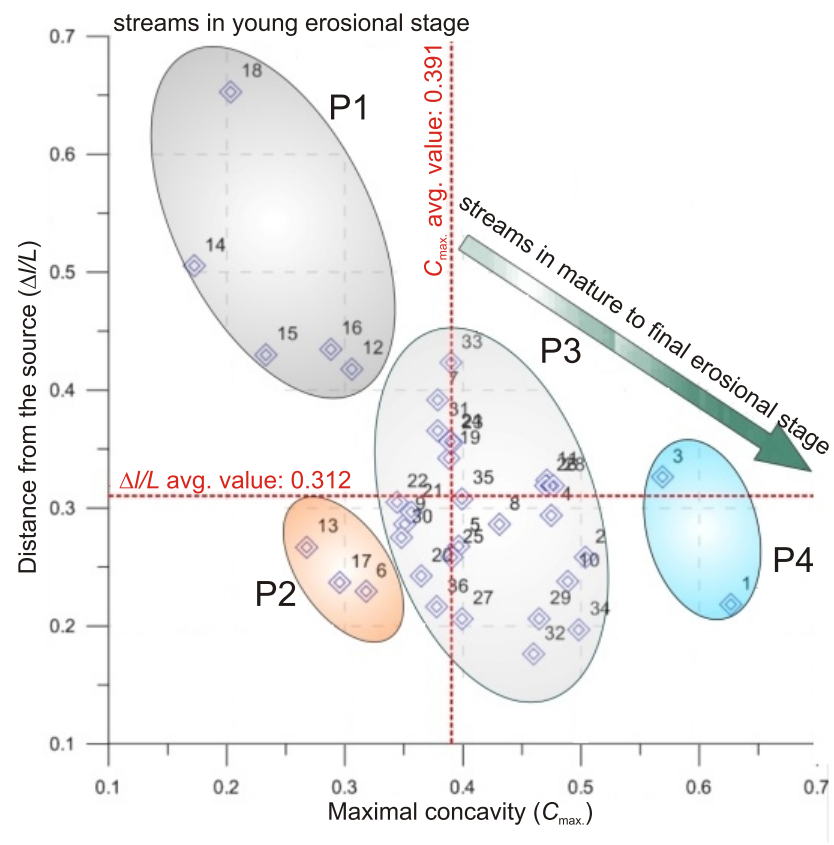

Fig. 10. Scatter plot of maximal concavity $\left(C_{\max }\right)$ and distance from the source $(\Delta I / L)$ values

Stream profile statistical parameters are clustered into four groups (P1, P2, P3 and P4); arrow indicates direction of increasing degree of equilibrium conditions (higher values of $C_{\max }$. and lower values of $\Delta / / L$ ); see Table 2 for drainage basin names and statistical stream parameters

low to moderate average $k_{s n}$ values in the range of 13.0-31.5. The fourth group, including drainage basins nos. 7, 8, 10-12, $16,18,23,25$ and 26 , is characterized by extremely high $\theta$ values $(1.001-1.86)$ and high to extremely high average $k_{s n}$ values (in the range between 43.47 and 87.9 ). In this group, the streams are located predominantly in the SW area of Mt. Medvednica and are characterized by major and minor knickpoints on relatively complex longitudinal profiles.
Furthermore, although quantitative data on rock strength are unavailable, we analysed stream profile parameters, i.e. $\theta$ values, average $k_{s n}$ values, and max. $k_{s n}$ values in conjunction with lithology and structural features, as shown on the geological map (Fig. 13 and Table 2). This analysis suggests a strong difference in calculated values for basins in the NE and SW area of the mountain, with the highest values in the drainage basins composed of ortho-metamorphic rocks. In the NE area, delineated drainage basins cluster predominantly into groups I and II, with only three drainage basins (nos. 31, 34 and 35) clustering into group III. There are also few streams (basins nos. 30 , 32 and 33; Figs. 12 and 13) in the NE area, characterized by few exposed knickpoints, however, these features are associated with the lithological contact of low-grade metamorphic units and Neogene sediments.

In case of the SW area, the streams show significant increase of $\theta$, average low $k_{s n}$ and max. $k_{s n}$ values (Table 2, Figs. 12 and 13). Delineated drainage basins in this area also cluster into groups I and II, however, there is significant number of drainage basins which cluster as group IV (basins nos. 7, 8, $10-12,16,18,23,25,26)$. The latter drainage basins are characterized by frequent occurrences of major and minor knickpoints along stream profiles, especially in the central part of Mt. Medvednica in contact zones of resistant greenschists with surrounding para-metamorphic rocks and Cretaceous-Paleocene sedimentary rocks. The highest $\theta$ values $(0.87-1.86)$, average $k_{s n}$ values (41.3-87.9), and max. $k_{s n}$ values between 57.88-120.39 are characteristic of drainage basins (nos. 7, 8, 12, 13, 15, 16 and 18) which occupy the NW slopes of the mountain, covered by mechanically similar lithological units (Fig. 13).

\section{DISCUSSION}

Mt. Medvednica is characterized by significant lithological variations within almost all analysed drainage basins. Hence, due to non-uniform spatial distribution of lithology and highly variable rock strength properties, delineation of morphometric parameters and their interpretation in correlation with possible

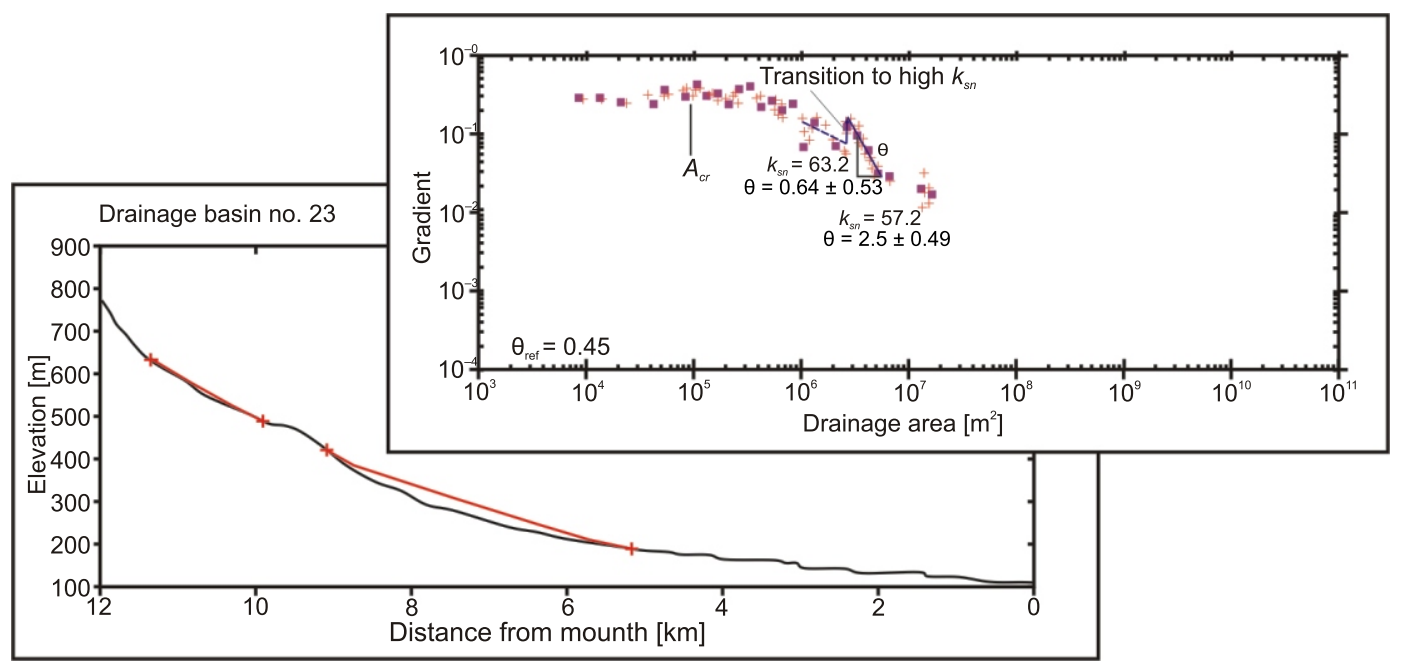

Fig. 11. Representative channel profile for drainage basin no. 23 in the study area

Insert longitudinal profile shows slope-area data, which is characterized by observed concavity index and normalized steepness index $k_{s n}$ (see text for details); black line fits the channel elevation data points with $\theta_{\text {ref }}=0.45$; red line represents channel profile derived from the best fit regression model 


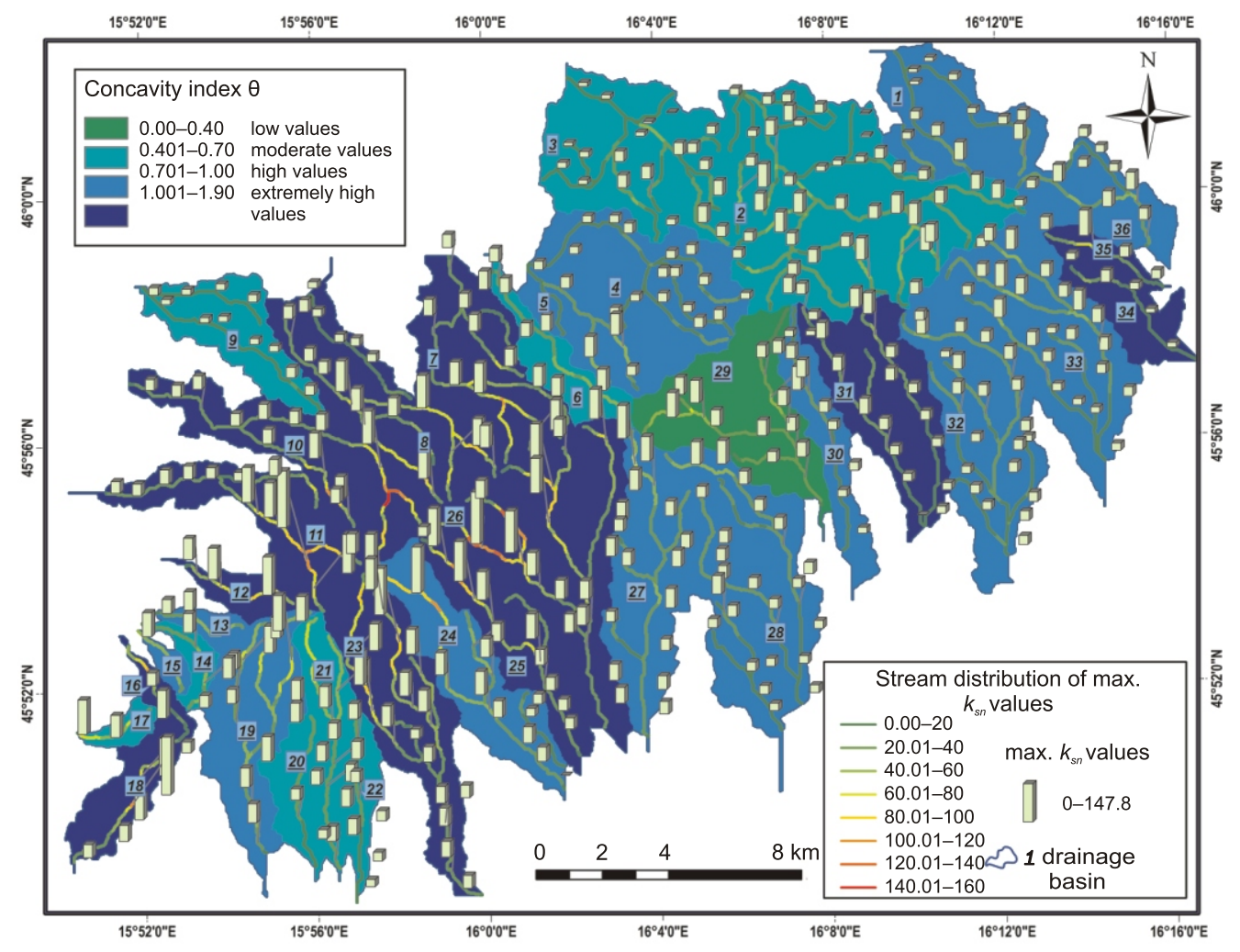

Fig. 12. Spatial distribution of max. $\boldsymbol{k}_{s n}$ values and observed $\theta$ values in the study area

Analysis was performed for every $200 \mathrm{~m}$ stream segment in each drainage basin

tectonic activity are a challenging task. Assuming a constant uplift of 0.17-0.4 mm/y (Šimunić and Šimunić, 1987; Prelogović and Velić, 1988; Kuk et al., 2000) and presumably uniform erosional rates during the Pliocene and Quaternary in this area, the obtained results of DEM-based morphometric analysis of the drainage basins suggest that the ongoing tectonic uplift is concentrated along: (1) the SW corner of the NW mountain front, and (2) the narrow boundary zone that divides Mt. Medvednica into NE and SW areas.

In the SW corner, tectonic uplift is revealed primarily by the hypsometric and longitudinal stream profile analysis. With pronounced convex curve shapes and $H_{i}$ values $>0.46$ (Fig. 6 and Table 1), the drainage basins show features of highly dissected landscape where erosional processes predominate over accumulation. The streams are rather short $(<4.5 \mathrm{~km})$, passing through V-shaped valleys characterized by convex longitudinal stream profiles (Fig. 8). The profile statistical parameters, concavity factor (16-40\%) and maximal concavity (0.173-0.318) positioned in the middle sections of longitudinal profiles indicate partly tectonically induced rejuvenation (possibly during the Quaternary) of stream profiles (Fig. 9). This interpretation is also confirmed by extremely high $\theta$ values $(0.87-1.86)$, average $k_{s n}$ values (41.3-87.9), and high to extremely high max. $k_{s n}$ values (57.88-120.39). The longitudinal stream profiles in this area are also characterized by the presence of major and minor knickpoints (Table 2). Although the lithology is not uniform in this area, Triassic, Cretaceous-Paleocene and Neogene clastic sediments (Fig. 13) show similar mechanical properties, so the possible strong lithological control on longitudinal stream profiles could be excluded here. However, in case of certain areas, e.g. basins nos. 15 and 18, the results of longitudinal profile analysis ( $\theta$ and $k_{s n}$ values) are considered questionable due to Late Triassic karstified carbonates that affect the validity of the basic assumption of the consistent power law relationship between stream discharge, channel gradient and drainage size [equation 5].

Nevertheless, the results that point to partly tectonically induced rejuvenation of streams in this area are in good agreement with the structural location of the southwestern segment of the NMBF which is interpreted as tectonically active by folding and faulting of basal Pliocene-Quaternary strata along it, and by a negative gravity anomaly positioned in the front of the southwestern termination of the mountain (Kuk et al., 2000; Tomljenović and Csontos, 2001; Verbič, 2005).

Besides hypsometry and stream profile analysis indicating a tectonic uplift and stream rejuvenation, the calculated asymmetry factor did not show any prominent surface tilting in the SW corner of Mt. Medvednica. The drainage basins show gentle asymmetries that converge towards the closure of SW-plunging antiform hinge, parallel to the orientation of strata and schistosity (Fig. 8). As exceptions, only drainage basins of minor transitional zone IV (Fig. 8) showed asymmetries, which could be interpreted either due to inclination of strata and schistosity in adjacent basins or due to a local tectonic tilting not yet recognized by geological mapping.

The ongoing tectonic activity along the narrow boundary zone that divides Mt. Medvednica into NE and SW areas is initially revealed by local relief distribution (Fig. 4A). Namely, this zone separates areas with significant local relief differences that attain 560 and $914 \mathrm{~m}$ in the NE and SW area, respectively. Geologically, this narrow boundary zone corresponds to the NW-striking Kašina Fault zone (Fig. 4B), which is interpreted as a right-lateral strike-slip fault by previous studies (e.g., Prelogović et al., 1998; Tomljenović and Csontos, 2001; Tomljenović et al., 2008). However, the significant local relief differences within the two fault sides suggest that, in addition to 


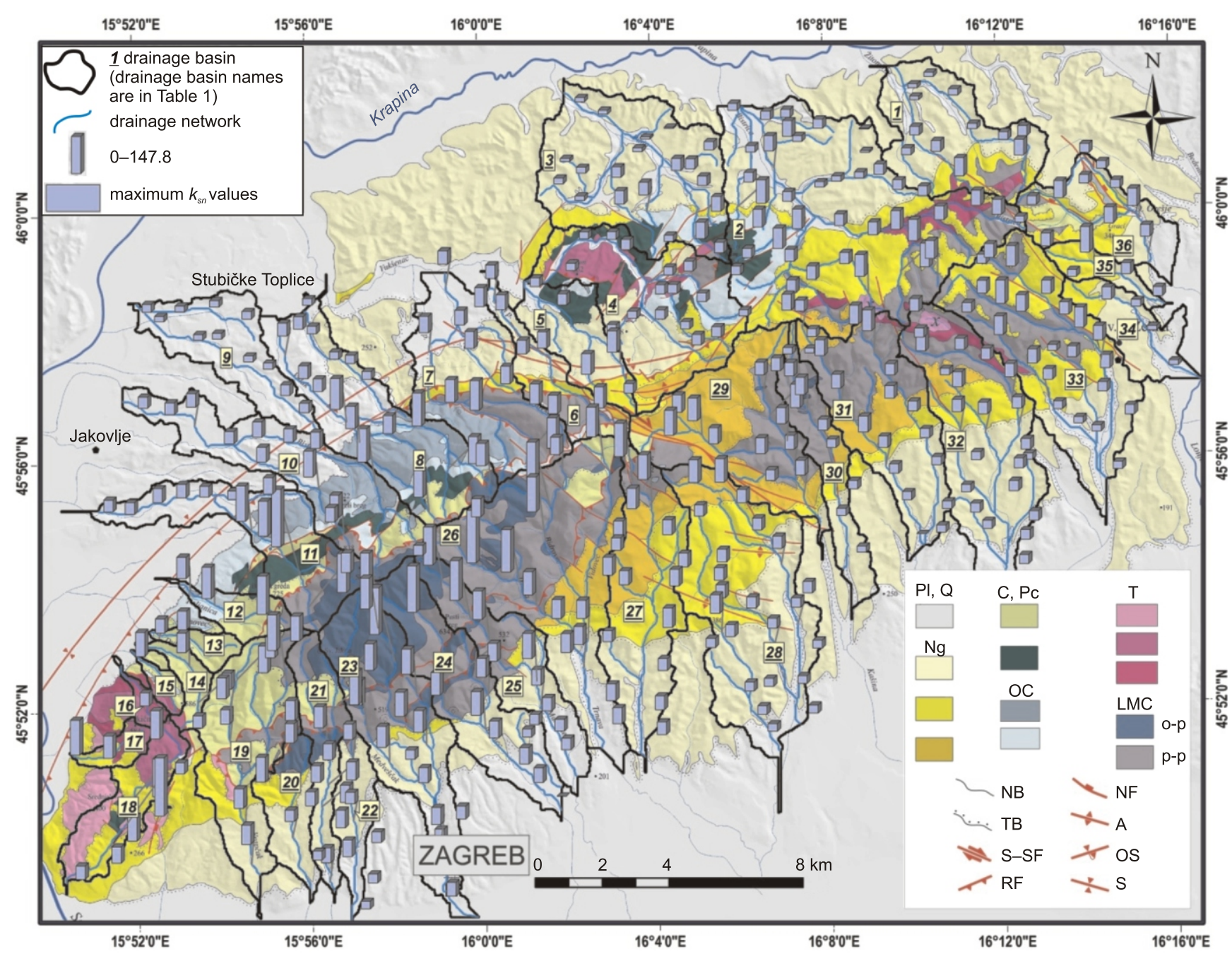

Fig. 13. Geological map of Mt. Medvednica overlapped by max. $\boldsymbol{k}_{s n}$ values

Note that the highest values are in the central and SW part of Mt. Medvednica; A - anticline, NB - normal boundary, NF - normal fault, OS overturned syncline, RF - reverse fault, S - syncline, S-SF - strike-slip fault, TB - transgressive boundary; PI, Q - Pliocene and Quaternary units, $\mathrm{Ng}$ - Neogene units, C, Pc - Cretaceous and Paleocene units, OC - ophiolitic complex, T - Triassic units, LMC - low metamorphic complex: o-p - ortho-protoliths, $p$ - $p$ - para-protoliths; see Figure 2 for detailed tectonostratigraphic unit description

the proposed right-lateral strike-slip component, this fault zone accommodated a prominent normal displacement. Ongoing tectonics in this zone is additionally proved by prominent changes in drainage basin asymmetry. Here, significantly tilted surface blocks with prominent basin asymmetries and abrupt changes in asymmetry directions sense, are well-documented (Fig. 8). These tilted blocks are separated by transitional zones I and II that include drainage basins nos. 6 and 26, 28 and 29. They either run parallel with or directly correspond with the Kašina Fault zone, respectively.

Tectonic activity in this zone is also supported by the prominent convex hypsometric curves and $H_{i}>0.40$. At the same time, the results of longitudinal stream profile analysis are not unambiguous. Statistical parameters of concavity factor $(40.2 \%)$, maximal concavity $(0.32)$, and distance from source $(0.23)$ of drainage basin no. 6 indicate a possible tectonic rejuvenation; however, the same parameters for basins nos. 26, 28 and 29 show characteristics closer to stream equilibrium conditions (Table 2, Figs. 9 and 10). The latter is also supported by low to moderate concavity index $(0.37-0.71)$, and $k_{s n}$ values (avg. $k_{s n}=26.1-36.9 ;$ max. $k_{s n}=50.11-60.2$ ) clustering drainage basins nos. 6, 28 and 29 into groups I and II. Exceptionally, only the stream of drainage basin no. 26 , with extremely high concavity index (1.7), high avg. $k_{s n}(53.25)$ and extremely high max. $k_{s n}$ values (139.44), could indicate possible tectonic activity (Fig. 13). However, frequent occurrences of major and minor knickpoints in this drainage basin are found to correspond with lithological contacts of more resistant greenschist and less resistant para-metamorphic, and Cretaceous-Paleocene rocks. Thus, we are in the opinion that longitudinal stream profile analysis in this area could not distinguish between possible tectonic uplift signal and lithological control.

Strong asymmetry is also seen to the NE of the Kašina Fault zone. Here, it possibly correlates with an en échelon set of NE-trending strike-slip faults (drainage basins nos. 3 and 4 ) and with NW-striking normal faults mapped at the NE end of the mountain (drainage basins 1 and 36). However, those areas cannot be reasonably assumed as tectonically active because local relief, hypsometry and longitudinal stream profile analysis point to streams characterized by low local relief values, concave hypsometric curves $\left(H_{i}<0.40\right)$, and longitudinal profile parameters, confirming stream equilibrium conditions, respectively (Table 1). 
The identified ongoing tectonic uplift within delineated areas also correlates well with moderate present-day seismicity with rare occurrences of strong earthquakes $\left(M_{L}>5\right)$ within major seismogenic sources in the Medvednica-Zagreb epicentral area (e.g., Prelogović et al., 1998; Herak et al., 2009 with references). The first delineated tectonically active area (alongside the SW corner of NW mountain front) coincides with the southwestern segment of the NMBF, a steeply SSE-dipping reverse fault zone, while the latter area (narrow boundary zone dividing Mt. Medvednica into the NE and SW regions) corresponds to the NW-striking Kašina Fault zone. This is also in good agreement with fault-plane solutions reported by Herak et al. (2009) and Pondrelli et al. (2006), and consequently sub-horizontal to moderately dipping $\mathrm{P}$-axis, predominantly $\mathrm{N}-\mathrm{S}$ directed in the central part, to NW-SE and NE-SE directed in the western and eastern parts of this area.

\section{CONCLUSIONS}

The DEM-based morphometric analysis with computed morphometric statistical parameters of drainage basins in Mt. Medvednica suggests that ongoing tectonic uplift is concentrated along the SW corner of the NW mountain front and along a narrow boundary zone that divides Mt. Medvednica into the NE and SW regions.

In the SW corner of Mt. Medvednica, tectonic uplift is revealed by hypsometric and longitudinal stream profile analysis. In addition to highly dissected landscape and short V-shaped valleys, streams are characterized by convex hypsometric curves and convex longitudinal stream profiles. Calculated statistical parameters $\left(H_{i}, C_{f}, C_{\max }, \Delta / / L, \theta\right.$ and $\left.k_{s n}\right)$ indicate tectonically induced rejuvenation marked by major and minor knickpoints. This is in good correlation with the structural location of the southwestern segment of the Northern Medvednica Boundary Fault which is reported as tectonically active by previous structural, seismotectonic and geophysical studies (Kuk et al., 2000; Tomljenović and Csontos, 2001; Verbič, 2005).
Morphometric results, which point to tectonically induced rejuvenation are only questionable for basins nos. 15 and 18 due to Late Triassic karstified carbonates that affect the validity of power law relationship described by equation [5].

The additional zone of possible tectonic uplift is initially identified in the Kašina Fault zone by local relief distribution. Considerable elevation differences between the NE and SW areas of Mt. Medvednica in combination with prominent basin asymmetries and abrupt changes in asymmetry directions sense were recognized in a narrow boundary zone associated with the NW-striking Kašina Fault zone. Although the NW-striking Kašina Fault zone was interpreted by previous studies (e.g., Prelogović et al., 1998; Tomljenović and Csontos, 2001; Tomljenović et al., 2008) as a right-lateral strike-slip fault, our study suggests that considerable local relief differences are probably a result of additional Kašina Fault normal movement. Tectonic uplift in this zone is also supported by hypsometry data; however, with longitudinal stream profile analysis $\left(C_{f}\right.$, $C_{\text {max., }}, \Delta / / L, \theta$ and $k_{s n}$ ) we have not been able to discriminate tectonic uplift signal from strong lithological control.

The identified areas correlate well with the southwestern segment of the North Medvednica Boundary Fault (steeply SSE-dipping reverse fault zone positioned alongside the SW corner of NW mountain front) and NW Kašina Fault zone (right-lateral strike-slip fault) which, according to Herak et al. (2009), represent a major seismogenic source for historical earthquakes and present-day seismicity.

Acknowledgements. This morphometric research was financially supported by the Ministry of Science, Education and Sports of the Republic of Croatia (Project CROTEC, grant No. 195-1951293-3155). The authors would like to thank Dr. J.V. Pérez-Peńa, Dr. M. Vrabec, and Dr. J. Weber for their constructive remarks and comments which significantly improved the quality of this manuscript. We are also grateful to Dr. T. Malvić for his positive comments, advices and technical support.

\section{REFERENCES}

Babić Lj., Gušić I., Nedela-Devidé D. (1973) Senonian breccias and overlying deposits on Mt. Medvednica (northern Croatia). Geološki Vjesnik, 25: 11-27.

Babić Lj., Hochuli P.A., Zupanič J. (2002) The Jurassic ophiolitic mélange in the NE Dinarides: Dating, internal structure and geotectonic implications. Eclogae Geologicae Helvetiae, 95: 263-275.

Basch O. (1981) Basic geological map 1:100 000, sheet Ivanić-Grad. Institute of Geology, Zagreb.

Beidinger A., Decker K., Roch K.H. (2011) The Lassee segment of the Vienna Basin fault system as a potential source of the earthquake of Carnuntum in the fourth century A.D. International Journal of Earth Science, 100: 1315-1329.

Belak M., Pamić J., Kolar-Jurkovšek T., Peckay Z., Karan D. (1995) Alpinski regionalnometamorfni kompleks Medvednice (sjeverozapadna Hrvatska). Zbornik radova, 1: 67-70. Croatian Geological Survey, Zagreb.

Bishop P. (2007) Long-term landscape evolution: linking tectonics and surface processes. Earth Surface Processes and Landforms, 32: 329-365.

Bognar A. (2001) Geomorfološka regionalizacija Hrvatske. Acta Geographica Croatica, 34: 7-29.
Bull W.B. (2009) Tectonically Active Landscapes. Wiley-Blackwell, Oxford.

Champel B., Beek P., van der, Mugnier J.-L., Leturmy P. (2002) Growth and lateral propagation of fault-related folds in the Siwaliks of western Nepal: rates, mechanisms, and geomorphic signature. Journal of Geophysical Research 107. DOI:10.1029/2001JB000578

Crnjaković M. (1980) Sedimentation of transgressive Senonian in Southern Mountain Medvednica. Geološki Vjesnik, 32: 81-95.

Crnjaković M. (1987) Sedimentology of Cretaceous and Palaeogene clastics of Mountain Medvednica, Ivanščica and Žumberak. Ph.D. thesis, University of Zagreb.

Csontos L., Nagymarosy A. (1998) The Mid-Hungarian line: a zone of repeated tectonic inversions. Tectonophysics, 297: 51-71.

Csontos L., Magyari Á., Vliet-Lanoë B., van, Musitz B. (2005) Neotectonics of the Somogy hills (Part II): evidence from seismic sections. Tectonophysics, 410: 63-80.

Cyr A.J., Granger D.E., Olivetti V., Molin P. (2010) Quantifying rock uplift rates using channel steepness and cosmogenic nuclide-determined erosion rates: examples from northern and southern Italy. Lithosphere, 2: 188-198. 
Ćorić S., Pavelić D., Rögl F., Mandić O., Vrabac S., Avanić R., Jerković L., Vranjković A. (2009) Revised Middle Miocene datum for initial marine flooding of North Croatian Basins (Pannonian Basin System, Central Paratethys). Geologia Croatica, 62: 31-43.

Delacaillau B., Carozza J.M., Laville E. (2006) Recent fold growth and drainage development: the Januari and Chandigarh anticlines in the Siwalik foothills, northwest India. Geomorphology, 76: 241-256.

Demoulin A. (1998) Testing the tectonic significance of some parameters of longitudinal river profiles: the case of the Ardenne (Belgium, NW Europe). Geomorphology, 24: 189-208.

Flint J.J. (1974) Stream gradient as a function of order, magnitude, and discharge. Water Resources Research, 10: 969-973.

Fodor L., Jelen B., Márton E., Skaberne D., Čar J., Vrabec M. (1998) Miocene-Pliocene tectonic evolution of the Slovenian Periadriatic fault: implications for Alpine-Carpathian extrusion models. Tectonics, 17: 690-709.

Gosar A. (1998) Seismic reflection surveys of the Krško basin structure: implications for earthquake hazard at the Krško nuclear power plant, southeast Slovenia. Journal of Applied Geophysics, 39: 131-153.

Gurenieri P., Pirrotta C. (2008) The response of drainage basins to the late Quaternary tectonics in the Sicilian side of the Messina Strait (NE Sicily). Geomorphology, 95: 260-273.

Hack J.T. (1973) Stream profile analysis and stream-gradient index U.S. Geological Survey Journal of Research, 1: 421-429.

Halamić J., Slovenec D., Kolar-Jurkovšek T. (1998) Triassic pelagic limestones in pillow lavas in the Orešje quarry near Gornja Bistra, Medvednica Mt. (Northwest Croatia). Geologia Croatica, 51: $33-45$.

Halamić J., Goričan Š., Slovenec D., Kolar-Jurkovšek T. (1999) Middle Jurassic radiolarite-clastic succession from the Medvednica Mt. (NW Croatia). Geologia Croatica, 52: 29-57.

Hamdouni R., el, Irigaray C., Fernández T., Cahacón J., Keller E.A. (2008) Assessment of relative active tectonics, southern border of the Sierra Nevada (southern Spain). Geomorphology, 96: 150-173.

Hećimović I. (1984) Strukturno-geomorfološka istraživanja između Medvednice, Ivanščice i Kalnika. Geološki Vjesnik, 37: 33-40.

Hećimović I. (2000) Morfostrukturni sklop Medvednice. Zbornik radova hrvatskog geološkog kongresa, Cavtat-Dubrovnik. Zagreb: 199-202.

Herak D., Herak M., Tomljenović B. (2009) Seismicity and earthquake focal mechanisms in North-Western Croatia Tectonophysics, 465: 212-220.

Holbrook J., Schumm S.A. (1999) Geomorphic and sedimentary response of rivers to tectonic deformation: a brief review and critique of a tool for recognizing subtle epirogenic deformation in modern and ancient settings. Tectonophysics, 305: 287-306.

Howard A.D., Kerby G. (1983) Channel changes in badlands. GSA Bulletin, 94: 739-752.

Huang X.J., Niemann J.D. (2006) An evaluation of the geomorphically effective event for fluvial processes over long periods. Journal of Geophysics Research - Earth Surface, 111: F03015.

Ismail E.H., Abdelsalam M.G. (2012) Morpho-tectonic analysis of the Tekeze River and the Blue Nile drainage systems on the Northwestern Plateau, Ethiopia. Journal of African Earth Sciences, 69: 34-47.

Judik K., Árkai P., Horváth P. (2004) Diagenesis and low-temperature metamorphism of Mt. Medvednica, Croatia: mineral assemblages and phyllosilicate characteristics. Acta Geologica Hungarica, 47: 151-176.

Judik K., Rantitsch G., Rainer Th.M., Árkai P., Tomljenović B. (2008) Organic metamorphism in metasedimentary rocks from Mt. Medvednica (Croatia). Swiss Journal of Geosciences, 101 605-616.

Keller E.A., Pinter N. (2002) Active Tectonics; Earthquakes, Uplift and Landscape. 2nd edition. Prentice-Hall, Upper Saddle River, New Jersey.
Keller E.A., Johnson D.L., Laduzinsky D.L., Seaver D.B., Ku T.L. (2000) Tectonic geomorphology of active folding over buried reverse faults: San Emigdio Mountain Front, Southern San Joaquin Valley, California. GSA Bulletin, 112: 86-97.

Kovačić M., Zupanič J., Babić Lj., Vrsaljko D., Miknić M., Bakrač K., Hećimović I., Avanić R., Brkić M. (2004) Lacustrine basin to delta evolution in the Zagorje Basin, a Pannonian sub-basin (Late Miocene: Pontian, NW Croatia). Facies, 50: 19-33.

Kuk V., Prelogović E., Sović I., Kuk K., Šariri K. (2000) Seismological and seismo-tectonical properties of the wider Zagreb area. Građevinar, 52: 647-653.

Lugović B., Šegvić B., Altherr R. (2006) Petrology and tectonic significance of greenschists from the Medvednica Mountains. (Sava Unit, NW Croatia). Ofioliti, 31: 39-50.

Márton E., Pavelić D., Tomljenović B., Avanić R., Pamić J., Márton P. (2002) In the wake of a counterclockwise rotating Adriatic microplate: Neogene paleomagnetic results from Northern Croatia. International Journal of Earth Sciences, 91: 514-523.

Mihalić S., Bernat S., Hamasaki E., Gerber N. (2011) Historica landslides in the City of Zagreb (Croatia): analysis of existing data. 2nd PROJECT WORKSHOP on Risk Identification and Land-Use Planning for Disaster Mitigation of Landslides and Floods (Book of Proceedings), University of Rijeka, Rijeka.

Pavelić D. (2001) Tectonostratigraphic model for the North Croatian and North Bosnian sector of the Miocene Panonian Basin System. Basin Research, 12, 359-376.

Peckham R., Jordan G. (2007) Digital Elevation Modeling. Development and Applications in a Policy Support Environment. Springer-Verlag, Berlin

Pedrera A., Pérez-Peńa J.V., Galindo-Zaldívar J., Azańón J.M., Azor A. (2009) Testing the sensitivity of geomorphic indices in areas of low-rate active folding (eastern Betic Cordillera, Spain). Geomorphology, 105: 218-231.

Pérez-Peńa J.V., Azańón J.M., Azor A. (2009) CalHypso: an ArcGIS extension to calculate hypsometric curves and their statistical moments. Applications to drainage basin analysis in SE Spain. Computer and Geosciences, 35: 1214-1223.

Pérez-Peńa J.V., Azor A., Azańón J.M., Keller E.A. (2010) Active tectonics in the Sierra Nevada (Betic Cordillera, SE Spain): insights from geomorphic indexes and drainage pattern analysis. Geomorphology, 119: 74-87.

Picotti V., Ponza A., Pazzaglia F.J. (2009) Topographic expression of active faults in the foothills of the Northern Apennines. Tectonophysics, 474: 285-294.

Pinter N. (2005) Applications of tectonic geomorphology for deciphering active deformation in the Pannonian Basin, Hungary. Occasional Papers of the Geological Institute of Hungary, 204: 45-51.

Placer L. (1999) Structural meaning of the Sava folds. Geologija, 41: 191-221.

Pondrelli S., Salimbeni S., Ekström G., Morelli A., Gasperini P., Vanucci G. (2006) The Italian CMT dataset from 1977 to the present. Physics of the Earth and Planetary Interiors, 159: 286-303.

Prelogović E. (1975) Neotektonska karta SR Hrvatske. Geološki Vjesnik, 28: 97-108.

Prelogović E., Velić J. (1988) Kvartarna tektonska aktivnost zapadnog dijela Dravske potoline. Geološki Vjesnik, 41: 237-253.

Prelogović E., Saftić B., Kuk V., Velić J., Dragaš M., Lučić D. (1998) Tectonic activity in the Croatian part of the Pannonian basin. Tectonophysics, 297: 283-293.

Rădoane M., Rădoane N., Dumitriu D. (2003) Geomorphological evolution of longitudinal river profiles in the Carpathians. Geomorphology, 50: 293-306.

Ratschbacher L., Frisch W., Linzer H.G., Merle O. (1991) Lateral extrusion in the Eastern Alps, part II: structural analysis. Tectonics, 10: $257-271$.

Ruszkiczay-Rüdiger Z., Fodor L., Horváth E., Telbisz T. (2009) Discrimination of fluvial, eolian and neotectonic features in a low 
hilly landscape: a DEM-based morphotectonic analysis in the Central Pannonian Basin, Hungary. Geomorphology, 104: 203-217.

Saftić B., Velić J., Sztanó O., Juhász G., Ivković Ž. (2003) Tertiary subsurface facies, source rocks and hydrocrbon resevoirs int he SW Part of the Pannonian Basin (Northern Croatia and South-Western Hungary). Geologia Croatica, 56: 101-122.

Schmid S.M., Bernoulli D., Fügenschuh B., Matenco L., Schefer S., Schuster R., Tischler M., Ustaszewski K. (2008) The Alpine-Carpathian-Dinaridic orogenic system: correlation and evolution of tectonic units. Swiss Journal of Geosciences, 101 139-183.

Schumm S.A., Dumont J.F., Holbrook J.M. (2000) Active Tectonics and Alluvial Rivers. Cambridge University Press, Cambridge.

Sikošek B. (1971) Explanatory notes for geological map of Yugoslavia, 1:500 000 (in Serbian). Federal Geological Institute, Beograd.

Slovenec D., Lugović B. (2008) Amphibole gabbroic rocks from the Mt. Medvednica ophiolite mélange (NW Croatia): geochemistry and tectonic settings. Geologica Carpathica, 59: 277-293.

Snow R.S., Singerland R.L. (1987) Mathematical modeling of graded river profiles. Journal of Geology, 95: 15-33.

Snyder N., Whipple K., Tucker G., Merritts D. (2000) Landscape response to tectonic forcing: DEM analysis of stream profiles in the Mendocino triple junction region, northern California. GSA Bulletin, 112: 1250-1263.

Strahler A.N. (1952) Hypsometric (area-altitude) analysis of erosional topography. GSA Bulletin, 63: 1117-1142.

Šikić K., Basch O., Šimunić A. (1977) Basic geological map 1:100 000, sheet Zagreb. Croatian Geological Survey, Federal Geological Institute, Beograd.

Šikić K., Basch O., Šimunić A. (1979) Explanatory notes for Geological map 1:100 000, sheet Zagreb (in Croatian). Institute of Geology Zagreb, Federal Geological Institute Beograd.

Šimunić A., Pikija M., Hećimović I. (1983) Basic geological map 1:100 000, sheet Varaždin. Institute of Geology Zagreb, Federal Geological Institute, Beograd.

Šimunić An., Šimunić Al. (1987) Rekonstrukcija neotektonskih zbivanja u sjeverozapadnoj Hrvatskoj na temelju analize pontskih sedimenata. Rad JAZU Zagreb, 431, Razred za prirodne znanosti, 22: 155-177.

Takšić A. (1965) Tectonics of Upper Oligocene deposits in Northwestern Croatia. Acta geologica, 5, Prirodoslovna istraživanja JAZU, 35: 269-285.

Tarboton D. (1997) A new method for the determination of flow directions and upslope areas in grid digital elevation models. Water Resources Research, 33: 309-319.

Tomljenović, B. (1995) Stratigraphic and tectonic position of sedimentary complex with basic magmatic rocks at northern slopes of the Medvednica (In Croatian with English summary). Ms.Sc.thesis. University of Zagreb.

Tomljenović B. (2002) Structural characteristics of Medvednica and Samoborsko gorje Mts. Ph.D. thesis, University of Zagreb.

Tomljenović B., Csontos L. (2001) Neogene-Quaternary structures in the border zone between Alps, Dinarides and Pannonian Basin (Hrvatsko zagorje and Karlovac Basin, Croatia). International Journal of Earth Sciences, 90: 560-578.
Tomljenović B., Csontos L., Márton E., Márton P. (2008) Tectonic evolution of northwestern Internal Dinarides as constrained by structures and rotation of Medvednica Mountains, North Croatia. Geological Society Special Publications, 298: 145-167.

Ustaszewski K., Schmid S.M., Lugović B., Schuster R., Schaltegger U., Bernoulli D., Hottinger L., Kounov A., Fügenschuh B., Schefer S. (2009) Late Cretaceous intra-oceanic magmatism in the internal Dinarides (northern Bosnia and Herzegovina): implication for the collision of the Adriatic and European plates. Lithos, 108: 106-125.

Velić J., Durn G. (1993) Alternating lacustrine-marsh sedimentation and subareal exposure phases during Quaternary: Prečko, Zagreb, Croatia. Geologia Croatica, 46: 71-90.

Velić J., Saftić B. (1991) Subsurface spreading and facies characteristics of Middle Pleistocene deposits between Zaprešić and Samobor. Geološki Vjesnik, 44: 69-82.

Velić J., Saftić B., Malvić T. (1999) Lithologic composition and stratigraphy of Quaternary sediments in the area of the "Jakuševec" waste depository (Zagreb, Northern Croatia). Geologia Croatica, 52: 119-130.

Verbič T. (2005) Quaternary stratigraphy and neotectonics of the Eastern Krško Basin, Part 2: Neotectonics. Razprave IV, razreda SAZU, 46: 171-216.

Vrabec M. (1999) Style of postsedimentary deformation in the Plio-Quaternary Velenje basin, Slovenia. Neues Jahrbuch für Geologie und Paläontologie, Monatshefte, 8: 449-463.

Vrsaljko D., Pavelić D., Miknić M., Brkić M., Kovačić M., Hećimović I., Hajek-Tadesse V., Avanić R., Kurtanjek N. (2006) Middle Miocene (Upper Badeninan/Sarmatian palaeoecology and evolution of the environments in the area of Medvednica Mt. (North Croatia). Geologia Croatica, 59: 51-63.

Whipple K.X. (2004) Bedrock rivers and the geomorphology of the active orogens. Annual Review of Earth and Planetary Sciences, 32: 151-185

Whipple K.X., Wobus C., Crosby B., Kirby E., Sheehan D. (2007) New tools for quantitative geomorphology extraction and interpretation of stream profiles from digital topographic data. GSA Annual Meeting Short Course.

Willgoose G., Hancock G. (1998) Revisiting the hypsometric curve as an indicator of form and process in transport-limited catchment. Earth Surface. Processes and Landforms, 23: 611-623.

Willingshofer E., Neubauer P., Cloetingh S. (1999): The significance of Gosau-type basins for the late Cretaceous tectonic history of the Alpine-Carpathian belt. Physics and Chemistry of the Earth Part A-Solid Earth and Geodesy, 24: 687-695.

Wobus C., Whipple K.X., Kirby E., Snyder N.P., Johnson J., Spyropolou K., Crosby B.T., Sheehan D. (2006) Tectonics from topography: procedures, promise, and pitfalls. GSA Special Paper, 398: 55-74.

Vrsaljko D., Mihalić S., Bošnjak M., Krkač M. (2011) Lithostratigraphical investigations of the Kostanjek landslide wider area: review of existing data and planned activities. 2nd PROJECT WORKSHOP on Risk Identification and Land-Use Planning for Disaster Mitigation of Landslides and Floods (Book of Proceedings), University of Rijeka, Rijeka. 